\title{
Bumble Bees (Hymenoptera: Apidae) of Montana
}

\section{Authors: Amelia C. Dolan, Casey M. Delphia, Kevin M. O'Neill, and Michael A. Ivie}

This is a pre-copyedited, author-produced PDF of an article accepted for publication in Annals of he Entomological Society of America following peer review. The version of record for (see citation below) is available online at: https://dx.doi.org/10.1093/aesa/saw064

Dolan, Amelia C., Casey M Delphia, Kevin M. O'Neill, and Michael A. Ivie. "Bumble Bees (Hymenoptera: Apidae) of Montana." Annals of the Entomological Society of America 110, no. 2 (September 2017): 129-144. DOI: 10.1093/aesa/saw064.

Made available through Montana State University's $\underline{\text { ScholarWorks }}$ scholarworks. montana.edu 


\title{
Bumble Bees (Hymenoptera: Apidae) of Montana
}

\author{
Amelia C. Dolan, ${ }^{1}$ Casey M. Delphia, ${ }^{1,2,3}$ Kevin M. O’Neill, ${ }^{1,2}$ and Michael A. Ivie ${ }^{1,4}$ \\ ${ }^{1}$ Montana Entomology Collection, Montana State University, Marsh Labs, Room 50, 1911 West Lincoln St., Bozeman, MT 59717 \\ (amelia.clare1229@gmail.com; casey.delphia@montana.edu; koneill@montana.edu; mivie@montana.edu), ${ }^{2}$ Department of Land \\ Resources and Environmental Sciences, Montana State University, Bozeman, MT 59717, ${ }^{3}$ Department of Ecology, Montana State \\ University, Bozeman, MT 59717, and ${ }^{4}$ Corresponding author, e-mail: mivie@montana.edu
}

Subject Editor: Allen Szalanski

Received 10 May 2016; Editorial decision 12 August 2016

\begin{abstract}
Montana supports a diverse assemblage of bumble bees (Bombus Latreille) due to its size, landscape diversity, and location at the junction of known geographic ranges of North American species. We compiled the first inventory of Bombus species in Montana, using records from 25 natural history collections and labs engaged in bee research, collected over the past 125 years, as well as specimens collected specifically for this project during the summer of 2015. Over 12,000 records are included, with 28 species of Bombus now confirmed in the state. Based on information from nearby regions, four additional species are predicted to occur in Montana. Of the 28 species, Bombus bimaculatus Cresson and Bombus borealis Kirby are new state records. The presence of $B$. borealis was previously predicted, but the presence of $B$. bimaculatus in Montana represents a substantial extension of its previously reported range. Four additional "eastern" bumble bee species are recorded from the state, and three species pairs thought to replace one another from the eastern to western United States are now known to be sympatric in Montana. Additionally, our data are consistent with reported declines in populations of Bombus occidentalis Greene and Bombus suckleyi Greene, highlighting a need for targeted surveys of these two species in Montana.
\end{abstract}

Key words: pollination, Apidae, natural history collection, museum, pollinator

Shrinking ranges and declining populations of wild and managed bees (Hymenoptera: Apoidea) have recently raised concerns worldwide (Chaplin-Kramer et al. 2014, Goulson et al. 2015). Hypotheses have been presented on causes of the observed declines, and predictions have been made about negative economic and environmental impacts (Holden 2006, Potts et al. 2010, Burkle et al. 2013). Factors proposed to play a role in population declines of pollinators include anthropogenic landscape and climate change, lack of high-quality forage, pathogens and parasites, pesticides, and competition with and pathogen transfer from nonnative or commercial bees (Winfree et al. 2009, Goulson et al. 2015, Kerr et al. 2015).

Bumble bees (Bombus spp.) are among the most recognizable bees due to their large size and colorful bodies. Because they have the ability to sonicate or "buzz pollinate" certain types of flowers, they are also some of the most important pollinators for wild and cultivated plants having poricidal anthers, such as huckleberries (Ericaceae) and tomatoes (Solanaceae) (Harder and Barclay 1994, De Luca and Vallejo-Marin 2013). Like other bees, bumble bees worldwide have experienced declines and range contractions over the past two decades (Williams and Osborne 2009, Cameron et al. 2011, Goulson et al. 2015). In the United States, Cameron et al. (2011) used historic records and intensive sampling of present-day communities to show that four species, Bombus affinis Cresson, Bombus occidentalis Greene, Bombus terricola Kirby, and Bombus pensylvanicus (DeGeer), have experienced drastic reductions in their historic ranges over the past 20-30 yr. Some estimates indicate that up to $25 \%$ of North American bumble bee species are facing some level of decline (Colla et al. 2012, Williams and Jepson 2014). In 2014, the International Union for Conservation of Nature (IUCN) Bumble Bee Specialist Group recommended five North American bumble bee species for "Critically Endangered" status, two for "Endangered" status, five for "Vulnerable" status, and one for "Near Threatened" status, while 28 species were considered to be of "Least Concern" (Williams and Jepson 2014). At least one Bombus Latreille species in North America, Bombus franklini Frison, known only from northern California and southern Oregon, may already be extinct (Williams et al. 2014).

Despite myriad studies focused on varying aspects of bumble bee biology amid concern over declining populations, large gaps in baseline knowledge still exist. There may be as many as 250 bumble bee species worldwide (Williams 1998, Michener 2007), and though bumble bees are relatively well-known, some regions have been better studied than others. In the United States, checklists, range maps, and population-monitoring studies have been published on the 
bumble bees of some states (e.g., Severin 1926, Thorp et al. 1983, Colla et al. 2011, Scott et al. 2011, Warriner 2012, Koch et al. 2012, Figueroa and Bergey 2015, Tripodi and Szalanski 2015), whereas other states have few published records.

In the United States, Montana is one of the least-studied areas with regards to bee species and distribution (Koch et al. 2015), partly because of a vast, sparsely populated area, much of which is difficult to access (Montana Wilderness Association 2015). Bumble bee range maps created using museum data and statistical models predicted that 25-30 species occur in Montana (Williams et al. 2014). Twenty-seven species have been reported in the literature (Franklin 1912; Frison 1923; Milliron 1971, 1973a,b; Koch et al. 2012; Williams et al. 2014), but some of these reports are based on a single locality. Furthermore, $<500$ specimens have been reported from the entire eastern half of the state, an area of $\sim 190,000 \mathrm{~km}^{2}$ (Williams et al. 2014).

Due to its large size, topographic diversity, and climatic variability, Montana supports vegetation zones ranging from relatively lowelevation, dry plains in the east to boreal and alpine zones in the west (Lesica 2012). Additionally, the state is at the junction of known eastern and western North American bumble bee ranges (Koch et al. 2012). Alpine environments connected to the arctic via Canada provide a habitat corridor for bumble bee species from the north, while xeric Great Basin elements approach from the south (Williams et al. 2014, Discover Life 2016). This diversity of landscapes and unique geographic placement make it likely that Montana contains a large assemblage of bumble bee species that differs from surrounding states or provinces.

Habitat and landscape changes have been cited as one of the primary factors threatening bumble bee populations (Williams and Osborne 2009, Goulson et al. 2015). Montana's history includes disturbances associated with mining, logging, agriculture, transportation, and recreation (Burlingame and Toole 1957, Wyckoff 2006). However, before we can determine if and how bumble bee populations are changing in Montana, a baseline understanding of the fauna is necessary.

The literature includes records of 27 species of bumble bees collected in Montana since 1883 (Table 1). Four other species (Bombus bohemicus Seidl, Bombus borealis Kirby, Bombus morrisoni Cresson, and Bombus ternarius Say) are recorded close to the Montana border (Williams et al. 2014), and several additional species are predicted to be here, based on proximity of neighboring populations, climatic suitability (sensu Williams et al. 2014), and geographic considerations (Milliron 1973b; Table 1).

Our objectives were to 1) create an inventory of Bombus species in the state, 2) provide county-level distribution data for each of these species, 3) create a taxonomic key to make identifications easier and more accurate for those working on Bombus in Montana, and 4) generate a greatly expanded dataset on the history, occurrence, and temporal distribution of bumble bees in Montana. This study was not meant to include ecological or conservation assessments, but to provide baseline data to inform future research and conservation efforts.

\section{Materials and Methods}

\section{Museum and Lab Collections}

Our inventory is based on 12,067 specimens of Bombus species from 25 North American natural history collections or research labs and four databases (Supp. Table 1 [online only]). The total number of specimens examined $(N=15,235)$ was larger because duplicates from long series of the same species from the same date, place, and time were examined to check for determination errors, but not every individual was databased (see Supp. Table 1 [online only]).

All specimens were identified using keys from current literature (Williams et al. 2014, Koch et al. 2012, Colla et al. 2011, Thorp et al. 1983, and Stephen 1957). Taxonomy followed Williams et al. (2014) for all species except Bombus fervidus (F.) and Bombus californicus Smith, which we consider to be separate species (see discussion), and Bombus kirbiellus Curtis as separate from Bombus balteatus Dahlbom, following recent DNA evidence (Williams et al. 2015). New state records, rare species, and difficult-to-identify specimens were verified by James Strange or Jonathan Koch at the Bee Biology and Systematics Laboratory (BLCU), Logan, UT, or Robbin Thorp at the University of California, Davis.

Initially, 3,003 specimens from the Montana Entomology Collection (MTEC) at Montana State University (MSU) were examined. Determinations were verified, corrected, or made, and each specimen was labeled with a unique identifier tag (barcode). Localities were georeferenced and verified or corrected, and all records were uploaded to the MTEC XBio:D database (mtent.org) managed through The Ohio State University (hol.osu.edu). Additionally, Bombus specimens deposited in other labs at MSU (Supp. Table 1 [online only]) were examined, determined, and databased.

Records of Bombus specimens collected in Montana were obtained from the BLCU database, the American Museum of Natural History (AMNH) database, the Yale University Peabody Museum of Natural History (PMNH) database, and from Leif Richardson's (Williams et al. 2014) database. These records were reviewed and other North American entomology collections were contacted for updated lists or loans. Requests for loans were made if there were 1) new state records, 2) new county records, 3) questionable determinations, 4) range discrepancies, and/or 5) undetermined Bombus from Montana. Two large, historic collections, the National Museum of Natural History (NMNH) and the Academy of Natural Sciences, Philadelphia (ANSP), with specimen data not available electronically, were visited and Montana specimens were sorted, identified, and added to the database. For all specimens, we verified or updated historic determinations, identified undetermined specimens, and added the records to the database.

\section{Field Sampling}

Historical data on Bombus from museum specimens revealed that Montana has been unevenly sampled, with especially low coverage in the eastern half of the state (Figs. 1-2). In April 2015, the database showed 4 of 56 counties with no Bombus records and 7 others with $<3$ species documented. To help remedy this, collecting was undertaken in the 2015 field season and focused on unsampled or undersampled regions of Montana. In cooperation with the Montana Department of Agriculture's Cooperative Agriculture Pest Survey (CAPS) program, 30 Japanese Beetle traps (Foley et al. 2011) and 29 yellow bucket traps (Brambila et al. 2014) were placed in 20 of Montana's 56 counties from March through August. In addition, between March and September, we collected bumble bees across the state, usually on flowers. Bumble bees collected by other labs at MSU and the U.S. Geological Survey (USGS) in Glacier National Park were also added to the database. Montana's County Extension Agents and Master Gardeners assisted with the project by sending Bombus specimens collected from various localities in the state.

Specimens were processed using standard procedures (Droege et al. 2012). Once cleaned, specimens were mounted, identified, and databased. Data were used to produce county-level range maps and graphs of each species' accumulation over time. 
Table 1. Summary of literature records of Bombus from Montana

\begin{tabular}{|c|c|}
\hline Citation & Bombus species documented \\
\hline Morrill 1903 & Recorded: Bombus atrifasciatus Morrill ${ }^{a}$, Bombus cooleyi Morrill ${ }^{b}$, Psithyrus $^{c}$ latitarsus Morrill $^{d}$, Psithyrus insularis $^{2}$ \\
\hline Franklin 1912 & $\begin{array}{l}\text { Recorded: B. appositus, B. centralis, Bombus edwardsii } \mathrm{Cresson}^{e} \text {, B. fervidus, B. flavifrons, B. huntii, B. kirbyellus }{ }^{f} \text {, B. mix- } \\
\text { tus, B. nevadensis, B. occidentalis, B. rufocinctus, Bombus separatus } \text { Cresson }^{g} \text {, B. vagans, Psithyrus consultus Franklin } \\
\text { P. insularis, P. latitarsus }{ }^{d} \\
\text { Predicted: B. californicus, B. frigidus, B. melanopygus, B. pensylvanicus, B. sitkensis, Psithyrus tricolor Franklin }{ }^{i}\end{array}$ \\
\hline Franklin 1915 & Recorded: B. californicus \\
\hline Anonymous 1920 & $\begin{array}{l}\text { Recorded: } \text { B. bifarius, B. centralis, B. occidentalis, B. rufocinctus (Species not listed in publication, but specimens are } \\
\text { deposited at the Academy of Natural Sciences, Philadelphia) }\end{array}$ \\
\hline Frison 1923 & Recorded: B. ternarius, B. terricola, B. vosnesenskii ${ }^{i}$ \\
\hline Kral 1955 & Recorded: B. edwardsii ${ }^{e}$, B. occidentalis, B. ternarius, B. terricola $^{k}$ \\
\hline Milliron 1971 & $\begin{array}{l}\text { Recorded: } \text { B. nevadensis, B. occidentalis } \\
\text { Predicted: B. auricomus, B. terricola }\end{array}$ \\
\hline Milliron 1973a & $\begin{array}{l}\text { Recorded: } \text { B. appositus, } \text { B. fervidus fervidus } \\
\text { Predicted: } \text { B. fervidus californicus, B. kirbyellus }{ }^{f} \text {, B. pensylvanicus }\end{array}$ \\
\hline Milliron 1973b & $\begin{array}{l}\text { Recorded: } \text { B. griseocollis } \\
\text { Predicted: } \text { B. morrisoni }\end{array}$ \\
\hline Hurd 1979 & Recorded: $B$. nevadensis auricomus, $B$. sitkensis, $B$. ternarius, $B$. terricola terricola, B. vagans vagans \\
\hline Bauer 1983 & $\begin{array}{l}\text { Recorded: } B \text {. appositus, } B \text {. bifarius nearcticus, } B \text {. flavifrons, } B \text {. frigidus, B. kirbyellus }{ }^{f}, B . \text { melanopygus, B. mixtus, B. neva- } \\
\text { densis nevadensis, B. occidentalis, B. sylvicola, P. insularis }\end{array}$ \\
\hline O’Neill et al.1991 & Recorded: B. griseocollis, B. nevadensis nevadensis, B. rufocinctus \\
\hline Fultz 2005 & $\begin{array}{l}\text { Recorded: B. appositus, B. californicus, B. edwardsii }{ }^{e} \text {, Bombus fernaldae (Franklin) }{ }^{i} \text {, B. fervidus, B. flavifrons, B. impa- } \\
\text { tiens', B. insularis, B. melanopygus, B. mixtus, B. occidentalis, B. rufocinctus, B. suckleyi }\end{array}$ \\
\hline Pearce et al. 2012 & Recorded: B. centralis, B. fervidus, B. griseocollis, B. huntii, B. rufocinctus, B. sp. \\
\hline Koch et al. 2012 & $\begin{array}{l}\text { Recorded: } B \text {. appositus, B. bifarius, B. californicus, B. centralis, B. fernaldae }{ }^{i} \text {, B. fervidus, B. flavifrons, B. frigidus, B. gri- } \\
\text { seocollis, B. huntii, B. insularis, B. melanopygus, B. mixtus, B. nevadensis, B. occidentalis, B. rufocinctus, B. sitkensis, } \\
\text { B. suckleyi, B. sylvicola, B. vagans } \\
\text { Predicted: Bombus balteatus Dahlbom }{ }^{a} \text {, B. morrisoni, B. ternarius, B. terricola }\end{array}$ \\
\hline $\begin{array}{l}\text { Simanonok and } \\
\text { Burkle } 2014\end{array}$ & $\begin{array}{l}\text { Recorded: B. appositus, B. balteatus }{ }^{a} \text {, B. bifarius bifarius, B. bifarius nearcticus, B. centralis, B. fernaldae }{ }^{i} \text {, B. flavifrons, B. } \\
\quad \text { frigidus, B. insularis, B. melanopygus, B. mixtus, B. nevadensis, B. sylvicola }\end{array}$ \\
\hline Williams et al. 2014 & 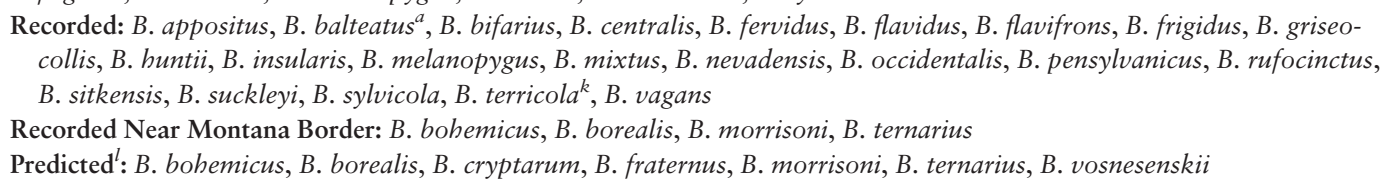 \\
\hline
\end{tabular}

${ }^{a}$ B. atrifasciatus $=$ B. balteatus (sensu Hurd 1979, sensu Williams et al. 2014) = B. kirbiellus Curtis (Williams et al. 2015).

${ }^{b}$ B. cooleyi $=$ B. bifarius (Hurd 1979).

${ }^{c}$ The genus Psithyrus is considered to be a subgenus of Bombus (Williams 1998).

${ }^{d}$ P. latitarsus $=$ B. suckleyi $($ Hurd 1979).

${ }^{e}$ B. edwardsii $=$ B. bifarius (Frison 1923) or B. melanopygus (Owen et al. 2010).

${ }^{f}$ Bombus kirbyellus is an unjustified emendation of B. kirbiellus Curtis (Williams et al. 2015).

${ }^{g}$ B. separatus $=$ B. griseocollis (Hurd 1979).

${ }^{\text {b }}$ P. consultus $=B$. insularis $($ Williams et al. 2014).

${ }^{i}$ P. tricolor $=$ B. fernaldae $($ sensu Hurd 1979) = B. flavidus (sensu Williams et al. 2014).

${ }^{j}$ This record is not verified, see discussion.

${ }^{k}$ Likely B. occidentalis, see discussion.

${ }^{l}$ Predicted via climatic suitability maps.

\section{Data Analysis}

Data were extracted from MTEC XBio:D database into Excel for analysis. County-level maps were created using a vector graphic from Wikipedia's U.S. Counties Map. The vector graphic code was edited in Adobe Dreamweaver and transferred to Adobe Illustrator using SVG Crowbar 2 plugin for final editing. The topographical map was created using Google My Maps. The map was saved as a PDF and copied into Adobe Photoshop for final editing.

The EstimateS (Colwell 2013) program was used to generate a Chao1 species richness prediction using each county as a sample. Species richness predictors estimate the total number of species present in a community. The Chao1 estimator is a commonly used species richness estimator that is based on the number of rare groups found in a sample (e.g., singleton taxa and doubleton taxa) to adjust for the number of species present but not detected by sampling
(Chao 1984, Gotelli and Colwell 2011). It is a lower bound estimate, and often underestimates the true parameter (Chao 1984), but is considered a good estimator of minimum species richness (Gotelli and Colwell 2011). A species accumulation curve was also generated using the EstimateS (Colwell 2013) program. Each county was considered a sample, and samples were randomized 50 times to create the mean accumulation curve.

\section{Results}

During the study, 12,067 Montana Bombus records were added to the MTEC XBio:D database. After sampling in all 56 counties (Fig. 3), 28 Bombus species are now known to occur in Montana (Table 2; Fig. 4). These species include two new state records, Bombus bimaculatus 

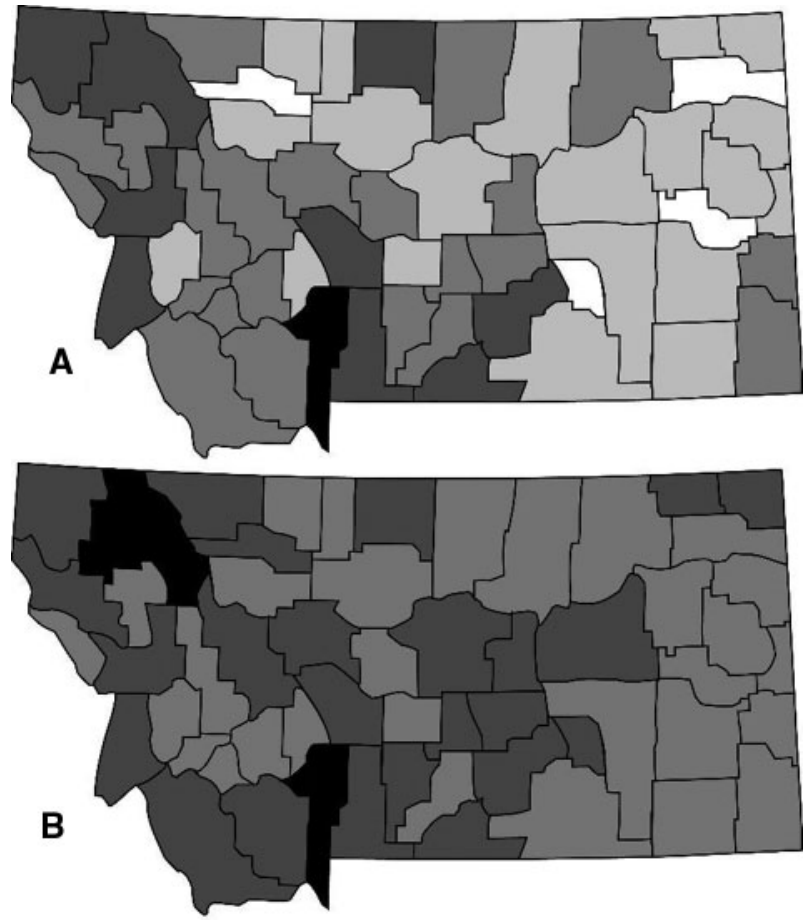

Fig. 1. Number of Bombus specimen records per Montana county in April 2015 (A) and January 2016 (B). White $=0$; light gray $=1-10$; medium gray $=11-100$; dark gray $=101-1,000$; black $>1,000$.
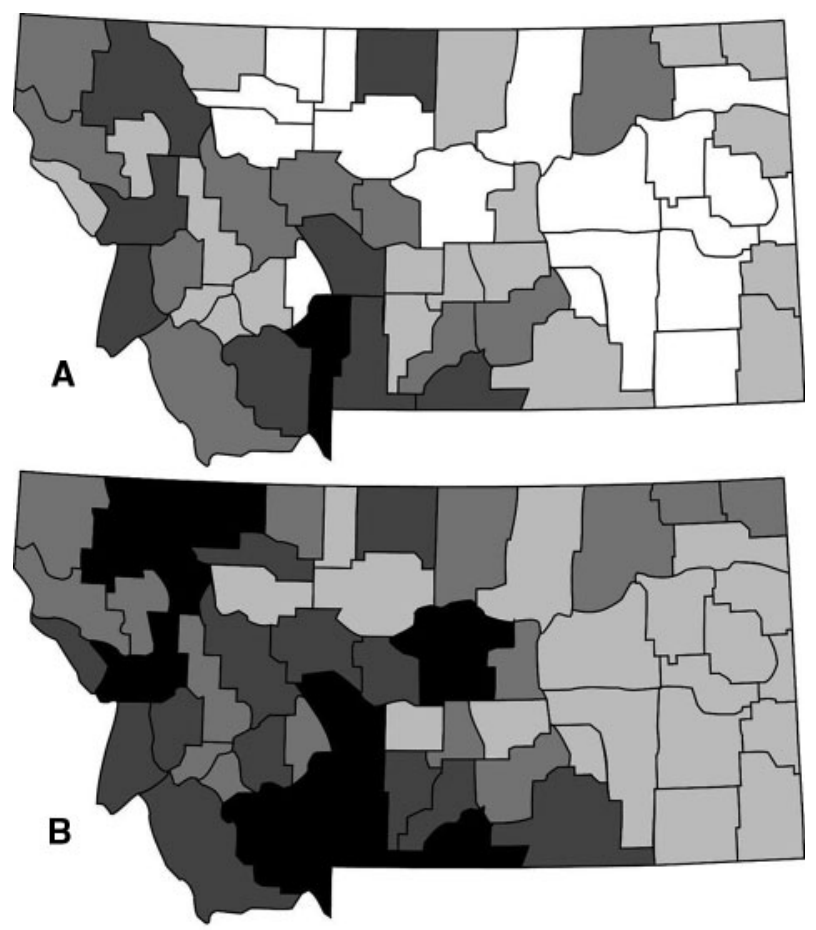

Fig. 2. Number of Bombus species records per Montana county in April 2015 (A) and January 2016 (B). White $=0-3$; light gray $=4-8$; medium gray $=9-12$; dark gray $=13-17$; black $=18-22$.

Cresson and B. borealis. Seven of the 28 are typically considered to have "eastern" United States ranges (Koch et al. 2012): Bombus auricomus (Robertson), B. bimaculatus, B. borealis, B. pensylvanicus, $B$. ternarius, B. terricola, and Bombus impatiens Cresson. The last is an eastern species that is reared for commercial purposes (see discussion for more details about its presence in Montana). Bombus vosnesenskii Radoszkowski is not included in our species list because no specimen from Montana could be found to verify Frison's (1923) literature record.

The mean species accumulation curve generated with the EstimateS program (Colwell 2013) reaches an asymptote at 28 species (Fig. 5). Additional analysis with the EstimateS program (Colwell 2013) yielded a Chao1 mean prediction of 28 species of Bombus for Montana ( $\mathrm{SD}=0.12 ; 95 \%$ confidence interval $=28.0$ 28.2 species). The variation in sampling methodology by many individuals over the past $130 \mathrm{yr}$, as well as the uneven spatial and temporal distributions of sampling prevents quantitative analyses of diversity and abundance comparisons by region. Nevertheless, the distribution maps (Fig. 4) and numbers of specimens per species presented here (Table 2) can provide insights into the relative abundance and ranges of Bombus species in Montana. It seems clear that species vary in abundance in the state as a whole. Of the 28 species, just 4 are represented by $>1,000$ specimens (Table 2). For another $16,>100$ specimens are in the database, but just 10 or fewer specimens were available for 4 species.

The oldest Montana specimens in the dataset were collected in 1883 (four individuals, NMNH). Sixty-three percent of the records in the database were collected between 1990 and 2015. The greatest accumulation of specimens (over 3,000) came in 2015, mostly from the current project. For a full discussion of the history of Bombus collecting in Montana, see Dolan (2016).

The intensive 2015 sampling did not uncover any new state records. There were, however, 113 new county records. Moreover, sampling in 2015 increased sample sizes and added species records for previously undersampled localities (Figs. 1-2). Excluding new records (where the divisor would be zero), increase in specimens per species from April 2015 to January 2016, ranged from 0\% for the special case of the introduced B. impatiens and $27 \%$ for native species B. sitkensis, to $900 \%$ for B. terricola, with a mean increase of $146 \%$ for the 27 native species.

\section{Discussion}

Bumble bee records are now available for all 56 of Montana's counties. The number of Bombus specimens collected in the state has greatly increased since 2000 due, not only to the sampling effort associated with the current project, but also to the general increase in pollinator research projects in Montana over the past $15 \mathrm{yr}$ (e.g., Fultz 2005, Cameron et al. 2011, Pearce et al. 2012, Simanonok and Burkle 2014). With the exception of two species, B. occidentalis and Bombus suckleyi Greene, all species have experienced at least a $49 \%$ increase in the number of specimens known from Montana since 2000.

Of the two new state records, B. borealis had previously been documented in Alberta and Saskatchewan, just north of Montana's border and just east of the state in North Dakota. Its presence in Montana was predicted, but never confirmed (Williams et al. 2014). The presence of $B$. bimaculatus is of special note because this species had previously not been documented or even predicted to be west of the eastern Dakotas and Nebraska (Williams et al. 2014). The discovery of this species in Montana represents a substantial westward extension of its known range.

Additional sampling is still needed to fully document the range and diversity of Bombus species in Montana since $>50 \%$ of Montana's counties (29/56) currently have $<100$ Bombus records 


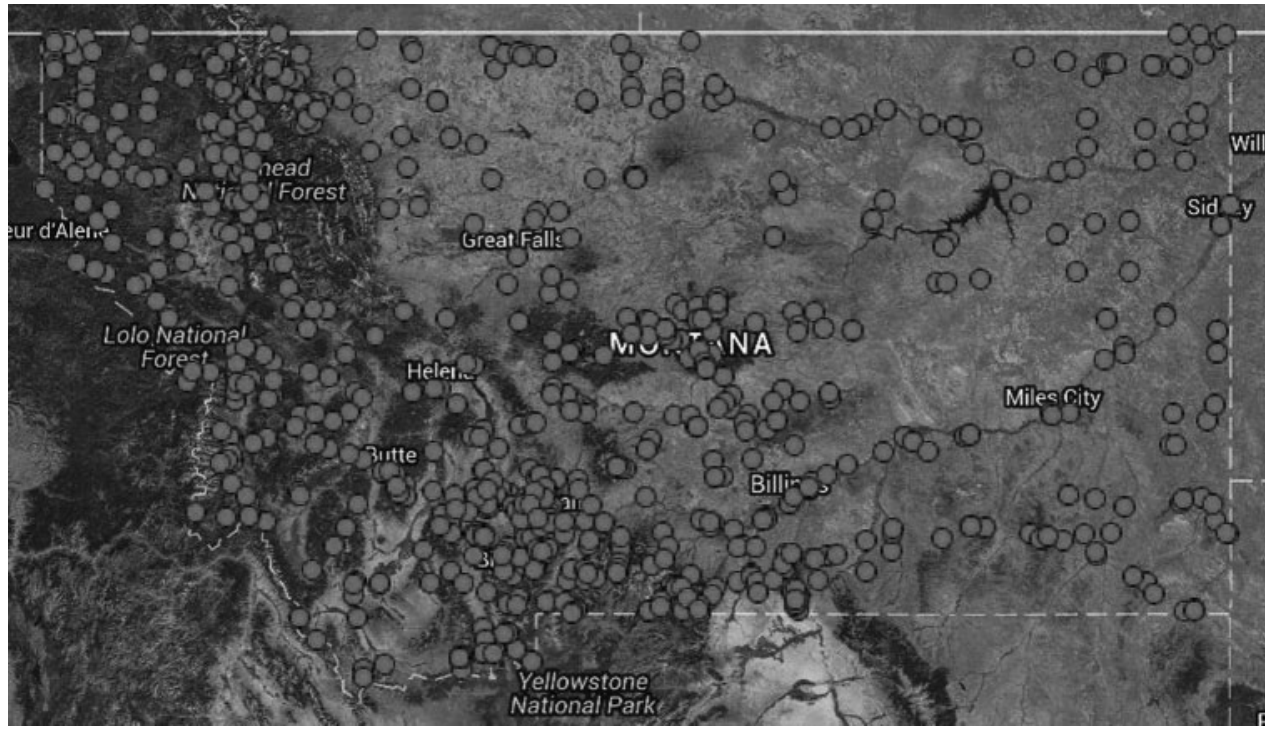

Fig. 3. Map of localities where Bombus specimens in Montana have been collected from 1883-2015. Map data 2016 Google, INEGI Imagery 2016 TerraMetrics.

(Table 2) and two counties only have 12 records. The entire state presents a diversity of habitat types, vegetation, and elevations that, if sampled more completely, could provide additional insights into state and North American range and population trends and might also reveal the presence of additional species.

\section{The Influence of Sampling Effort}

Geographic variation in past sampling effort is certainly a factor in interpreting the data presented here. The counties where entomologists have conducted research projects not necessarily focused on survey work (e.g., Gallatin, Flathead, Carbon, and Meagher) have the most species (Fig. 2). Additionally, the map of collection sites in Montana (Fig. 3) matches up well with the state's major highways, indicating that much of the historical sampling of Bombus has been convenience sampling. Also, at least two of the projects that contributed data targeted limited subsets of Bombus species (O’Neill et al. 1991, Cameron et al. 2011), which may have skewed our relative abundance data for their targeted species. O'Neill et al. (1991) preferentially collected Bombus griseocollis (DeGeer), Bombus nevadensis Cresson, and Bombus rufocinctus Cresson. Cameron et al. (2011) did the same for Bombus bifarius Cresson and B. occidentalis. Thus, the number of these species in our data set may not accurately reflect their actual relative abundance in the communities sampled. Furthermore, collecting in Lincoln and Sanders Counties in 2014 was part of a study focusing on insects associated with the huckleberry plant (Vaccinium globulare Rydberg; Dolan 2016). Bumble bees were only collected in specific habitats from V. globulare, so these counties in northwest Montana almost certainly have more Bombus species than the data suggest.

\section{Unrecorded Bombus Potentially Present in Montana}

The Chao1 mean prediction of 28 Bombus species in Montana (Fig. 5) indicates that we are unlikely to find more species than we have already documented. However, based on proximity of neighboring populations, climatic suitability (sensu Williams et al. 2014), and geographic considerations (Milliron 1973b), there are four Bombus species not yet recorded from Montana that may still be found. One of these is Bombus cryptarum (F.), whose range is recorded as the tundra/taiga regions of the northern Rocky Mountains from Alaska through southwestern Canada and across northwestern Canada to the Hudson Bay (Williams et al. 2014). The Canadian Rocky Mountains provide a continuous alpine environment south into northwestern Montana, allowing for the possibility of the occurrence of B. cryptarum. Records from Canada show this species has been collected within $20 \mathrm{~km}$ of Montana's northern border near Milk River, Alberta (Ashton Sturm, personal communication, specimens in Jessamyn Manson Lab Collection, University of Alberta).

Predictive habitat suitability maps extend the possible range of B. morrisoni from the deserts in the southwestern United States to the dry scrubland regions of southwestern Montana (Williams et al. 2014). There are records of this species in parts of Idaho near Montana, including one from Salmon, ID, just $17 \mathrm{~km}$ southwest of the border (Discover Life 2016). There are also records of B. morrisoni in southern Wyoming (Williams et al. 2014, Discover Life 2016); thus, it is possible that the range of B. morrisoni extends into southwest Montana (e.g., Beaverhead County).

Bombus bohemicus has been recorded from New England across the Midwestern United States and then north and west across western Canada to Alaska (Williams et al. 2014). It has not been documented from Montana, but there are records just to the north in Alberta and Saskatchewan, Canada (Williams et al. 2014). This species is very similar to B. suckleyi, which is also in the subgenus Psithyrus and is thought to replace B. bohemicus in parts of the West (R. Thorp, personal communication). Montana, especially northeastern Montana, is a place where the ranges of these two species may overlap, though both of these species are apparently in decline (Williams et al. 2014).

None of the published predictive maps extend the possible range of Bombus perplexus Cresson into Montana (Williams et al. 2014). However, there are records of $B$. perplexus collected across the eastern United States to Minnesota (Williams et al. 2014), and we added a record from Calgary, $225 \mathrm{~km}$ north of the Montana border (Museum of Zoology, University of Calgary (BDUC) \#MTEC 019296). This distribution pattern, which is similar to B. borealis 
Table 2. The 28 Bombus species occurring in Montana, organized alphabetically by species

\begin{tabular}{|c|c|c|c|c|}
\hline Species & Earliest specimen (Year) & First literature record & Total no. of specimens & Total no. of counties \\
\hline $\begin{array}{l}\text { Bombus (Subterraneobombus) appositus } \\
\text { Cresson, } 1878\end{array}$ & 1899 & Franklin 1912 & 302 & 25 \\
\hline $\begin{array}{l}\text { Bombus (Bombias) auricomus } \\
\text { (Robertson, 1903) }\end{array}$ & 1971 & Hurd 1979 & 5 & 4 \\
\hline $\begin{array}{l}\text { Bombus (Pyrobombus) bifarius } \\
\text { Cresson, } 1878\end{array}$ & 1883 & Morrill 1903 & 1,911 & 37 \\
\hline $\begin{array}{l}\text { Bombus (Pyrobombus) bimaculatus } \\
\text { Cresson, } 1863\end{array}$ & 2011 & New State Record & 18 & 7 \\
\hline $\begin{array}{l}\text { Bombus (Subterraneobombus) borealis } \\
\text { Kirby, } 1837\end{array}$ & $1926^{a}$ & New State Record ${ }^{b}$ & 20 & 8 \\
\hline $\begin{array}{l}\text { Bombus (Thoracobombus) californicus } \\
\text { Smith, } 1854\end{array}$ & 1913 & Franklin 1915 & 91 & 19 \\
\hline $\begin{array}{l}\text { Bombus (Pyrobombus) centralis } \\
\text { Cresson, } 1864\end{array}$ & $1901^{a}$ & Franklin 1912 & 641 & 47 \\
\hline $\begin{array}{l}\text { Bombus (Thoracobombus) fervidus } \\
\text { (F., 1798) }\end{array}$ & $1899^{a}$ & Franklin 1912 & 688 & 47 \\
\hline $\begin{array}{l}\text { Bombus (Psithyrus) flavidus } \\
\text { Eversmann, } 1852\end{array}$ & $1929^{b}$ & Fultz 2005 & 158 & 19 \\
\hline $\begin{array}{l}\text { Bombus (Pyrobombus) flavifrons } \\
\text { Cresson, } 1863\end{array}$ & 1900 & Franklin 1912 & 488 & 30 \\
\hline $\begin{array}{l}\text { Bombus (Pyrobombus) frigidus } \\
\text { Smith, } 1854\end{array}$ & 1929 & Bauer 1983 & 59 & 9 \\
\hline $\begin{array}{l}\text { Bombus (Cullumanobombus) griseocollis } \\
\text { (DeGeer, 1773) }\end{array}$ & 1904 & Franklin 1912 & 357 & 38 \\
\hline $\begin{array}{l}\text { Bombus (Pyrobombus) huntii } \\
\text { Greene, } 1860\end{array}$ & $1883^{a}$ & Franklin 1912 & 1,840 & 53 \\
\hline $\begin{array}{l}\text { Bombus (Pyrobombus) impatiens } \\
\text { Cresson, } 1863\end{array}$ & 1980 & Fultz $2005^{\mathrm{c}}$ & 7 & 2 \\
\hline $\begin{array}{l}\text { Bombus (Psithyrus) insularis } \\
\text { (Smith, 1861) }\end{array}$ & 1899 & Morrill 1903 & 389 & 30 \\
\hline $\begin{array}{l}\text { Bombus (Alpinobombus) kirbiellus } \\
\text { Curtis, } 1835\end{array}$ & 1900 & Morrill 1903 & 122 & 7 \\
\hline $\begin{array}{l}\text { Bombus (Pyrobombus) melanopygus } \\
\text { Nylander, } 1848\end{array}$ & 1913 & Franklin 1912 & 379 & 19 \\
\hline $\begin{array}{l}\text { Bombus (Pyrobombus) mixtus } \\
\text { Cresson, } 1878\end{array}$ & 1900 & Franklin 1912 & 855 & 30 \\
\hline $\begin{array}{l}\text { Bombus (Bombias) nevadensis } \\
\text { Cresson, } 1874\end{array}$ & $1899^{a}$ & Franklin 1912 & 252 & 41 \\
\hline $\begin{array}{l}\text { Bombus (Bombus) occidentalis } \\
\text { Greene, } 1858\end{array}$ & $1899^{a}$ & Franklin 1912 & 1,046 & 41 \\
\hline $\begin{array}{l}\text { Bombus (Thoracobombus) pensylvanicus } \\
\text { (DeGeer, 1773) }\end{array}$ & 1964 & Williams et al. 2014 & 5 & 4 \\
\hline $\begin{array}{l}\text { Bombus (Cullumanobombus) rufocinctus } \\
\text { Cresson, } 1863\end{array}$ & 1899 & Franklin 1912 & 1,391 & 52 \\
\hline $\begin{array}{l}\text { Bombus (Pyrobombus) sitkensis } \\
\text { Nylander, } 1848\end{array}$ & $1934^{b}$ & Hurd 1979 & 180 & 8 \\
\hline $\begin{array}{l}\text { Bombus (Psithyrus) suckleyi } \\
\text { Greene, } 1860\end{array}$ & 1899 & Morrill 1903 & 146 & 19 \\
\hline $\begin{array}{l}\text { Bombus (Pyrobombus) sylvicola } \\
\text { Kirby, } 1837\end{array}$ & 1913 & Bauer 1983 & 187 & 18 \\
\hline $\begin{array}{l}\text { Bombus (Pyrobombus) ternarius } \\
\text { Say, } 1837\end{array}$ & $1931^{a}$ & Frison 1923 & 301 & 18 \\
\hline $\begin{array}{l}\text { Bombus (Bombus) terricola } \\
\text { Kirby, } 1837\end{array}$ & $2011^{a}$ & Frison $1923^{\mathrm{d}}$ & 10 & 2 \\
\hline $\begin{array}{l}\text { Bombus (Pyrobombus) vagans } \\
\text { Smith, } 1854\end{array}$ & 1901 & Franklin 1912 & 152 & 18 \\
\hline
\end{tabular}

\footnotetext{
${ }^{a}$ Some specimens at ANSP have no recorded collection date. They were determined by Franklin in 1922, and may be part of E.T. Cresson's collection, which means they may have been collected as early as the mid-18th century (J. Weintraub personal communication).

${ }^{b}$ This species was predicted, but not confirmed, by earlier literature to be in Montana.

${ }^{c}$ This record of $B$. impatiens could not be verified. See text.

${ }^{d}$ The specimen recorded by Frison (1923) is likely B. occidentalis. See text.
} 


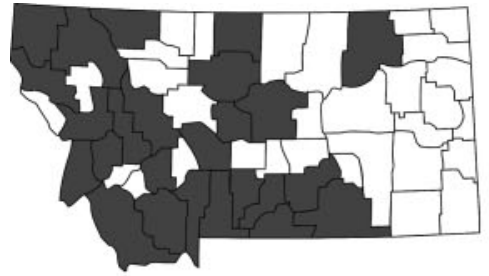

Figure 4a: Bombus appositus in MT 302 records from 25 counties.

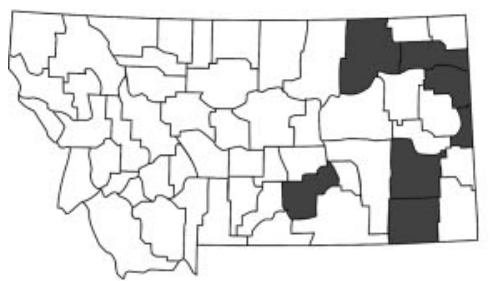

Figure 4d: Bombus bimaculatus in MT 18 records from 7 counties.

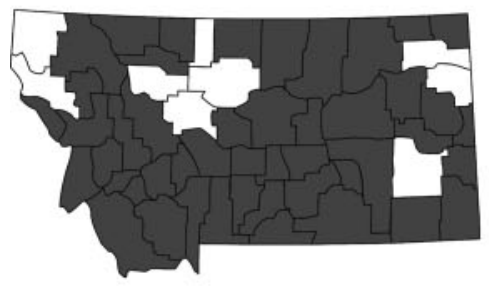

Figure 4g: Bombus centralis in MT 641 records from 47 counties.

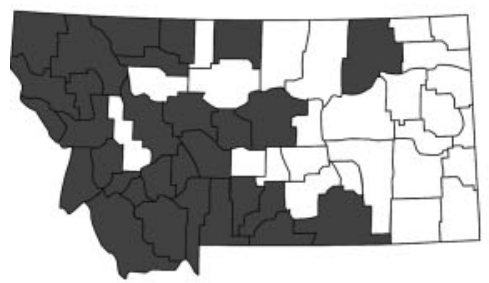

Figure 4j: Bombus flavifrons in MT 488 records from 30 counties.

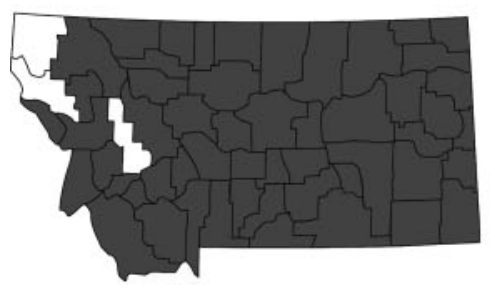

Figure 4m: Bombus huntii in MT 1,840 records from 54 counties.

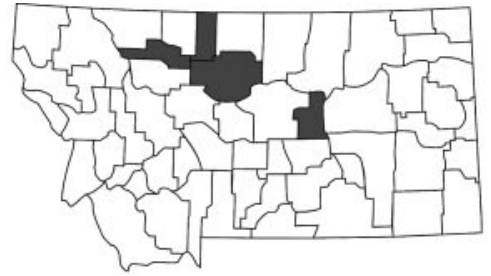

Figure 4b: Bombus auricomus in MT 5 records from 4 counties.

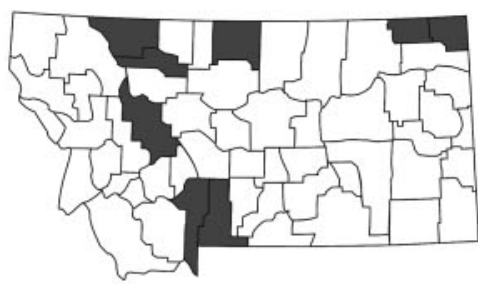

Figure 4e: Bombus borealis in MT 20 records from 8 counties.

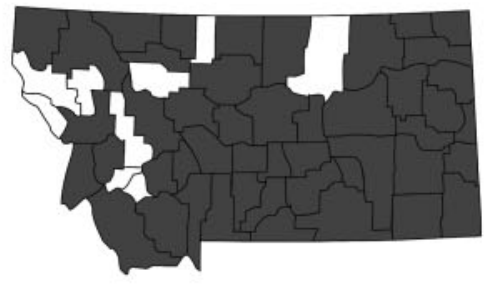

Figure 4h: Bombus fervidus in MT 688 records from 47 counties.

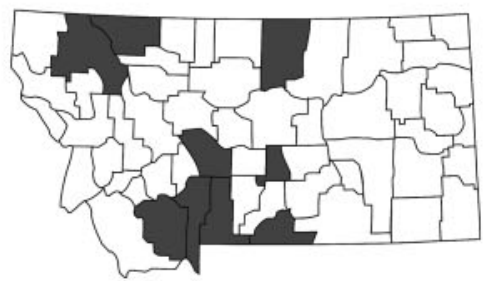

Figure 4k: Bombus frigidus in MT 59 records from 9 counties.

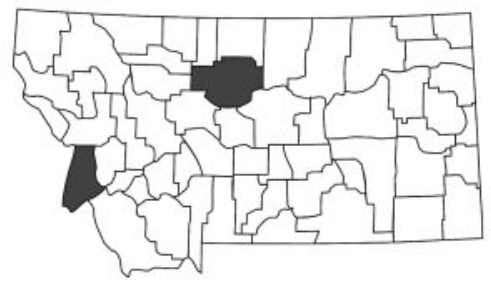

Figure 4n: Bombus impatiens in MT 7 records from 2 counties.

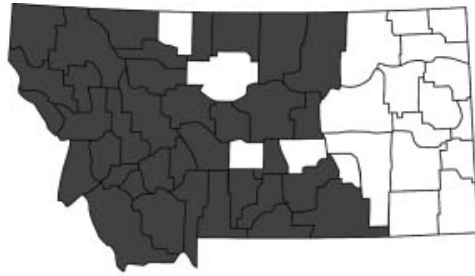

Figure 4c: Bombus bifarius in MT 1,911 records from 37 counties.

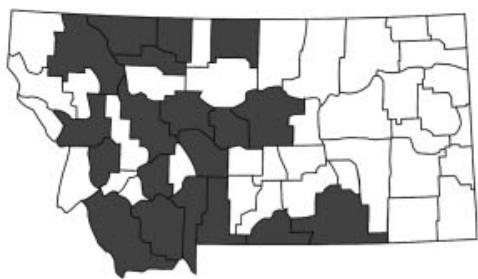

Figure 4f: Bombus californicus in MT 91 records from 19 counties.

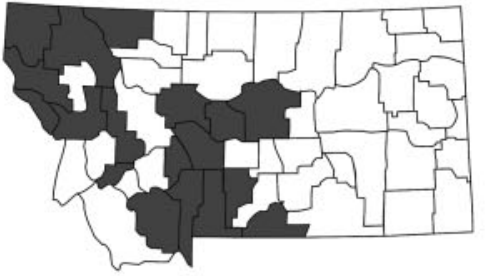

Figure 4i: Bombus flavidus in MT 158 records from 19 counties.

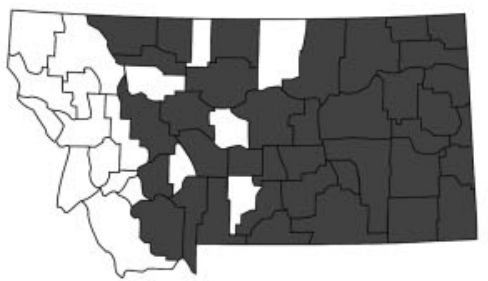

Figure 4I: Bombus griseocollis in MT 357 records from 38 counties.

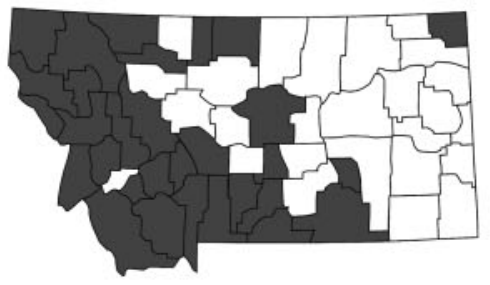

Figure 40: Bombus insularis in MT 389 records from 30 counties.

Fig. 4. (a-ab). County-level distribution maps for the 28 Bombus species known to occur in Montana. Note that the map of $B$. impatiens, Figure $4 \mathrm{n}$, is documenting 1) the presence of bees introduced for research in Chouteau County and 2) a distribution outlier in Ravalli County. See text for details. 


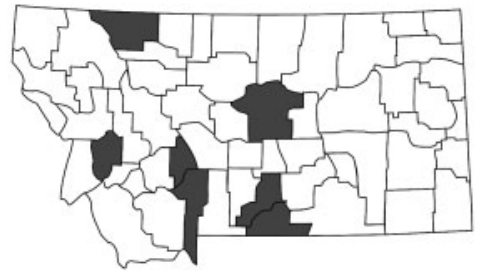

Figure 4p: Bombus kirbiellus in MT 122 records from 7 counties.

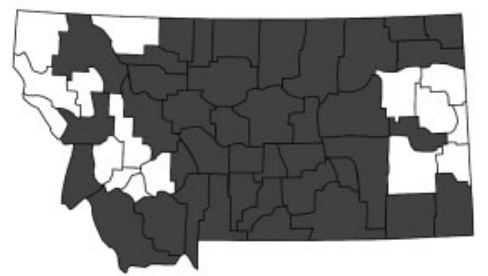

Figure 4s: Bombus nevadensis in MT 252 records from 41 counties.

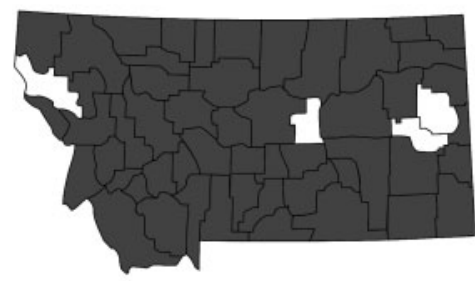

Figure 4v: Bombus rufocinctus in MT 1,391 records from 52 counties.

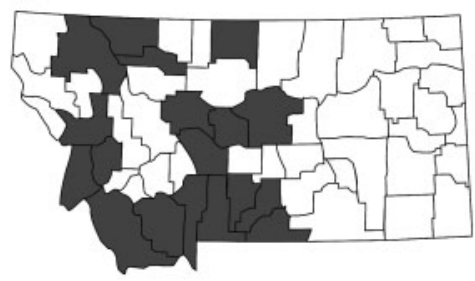

Figure 4y: Bombus sylvicola in MT 187 records from 18 counties.

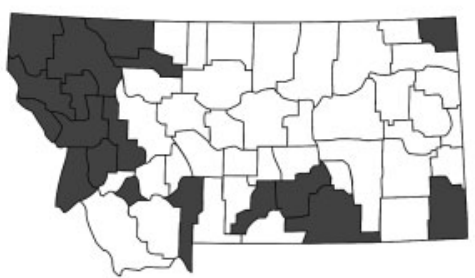

Figure 4ab: Bombus vagans in MT 152 records from 18 counties.

Fig. 4. (a-ab). Continued.

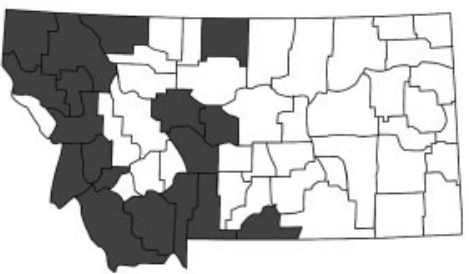

Figure 4q: Bombus melanopygus in MT 379 records from 19 counties.

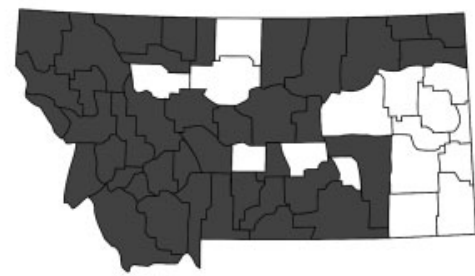

Figure 4t: Bombus occidentalis in MT 1,046 records from 41 counties.

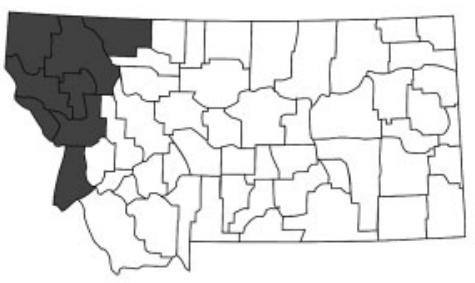

Figure 4w: Bombus sitkensis in MT 180 records from 8 counties.

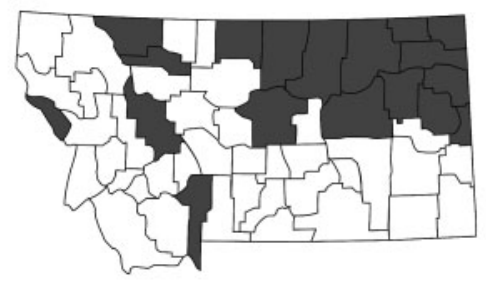

Figure 4z: Bombus ternarius in MT 301 records from 18 counties.

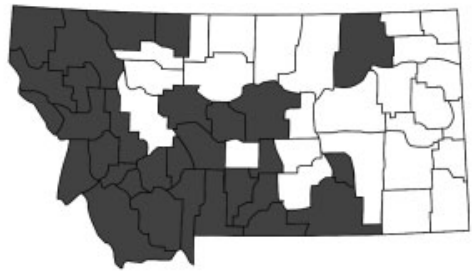

Figure 4r: Bombus mixtus in MT 855 records from 30 counties.

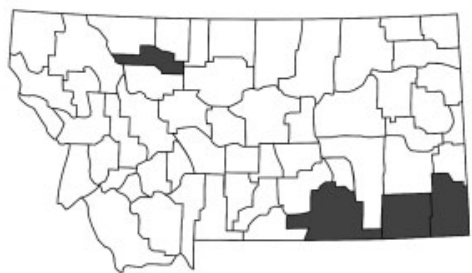

Figure 4u: Bombus pensylvanicus in MT 5 records from 4 counties.

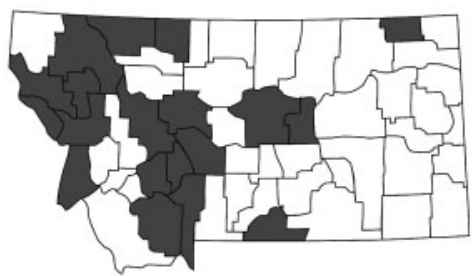

Figure 4x: Bombus suckleyi in MT 146 records from 19 counties.

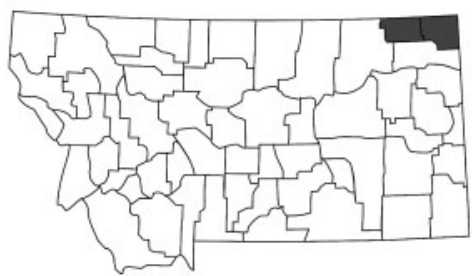

Figure 4aa: Bombus terricola in MT 10 records from 2 counties. 


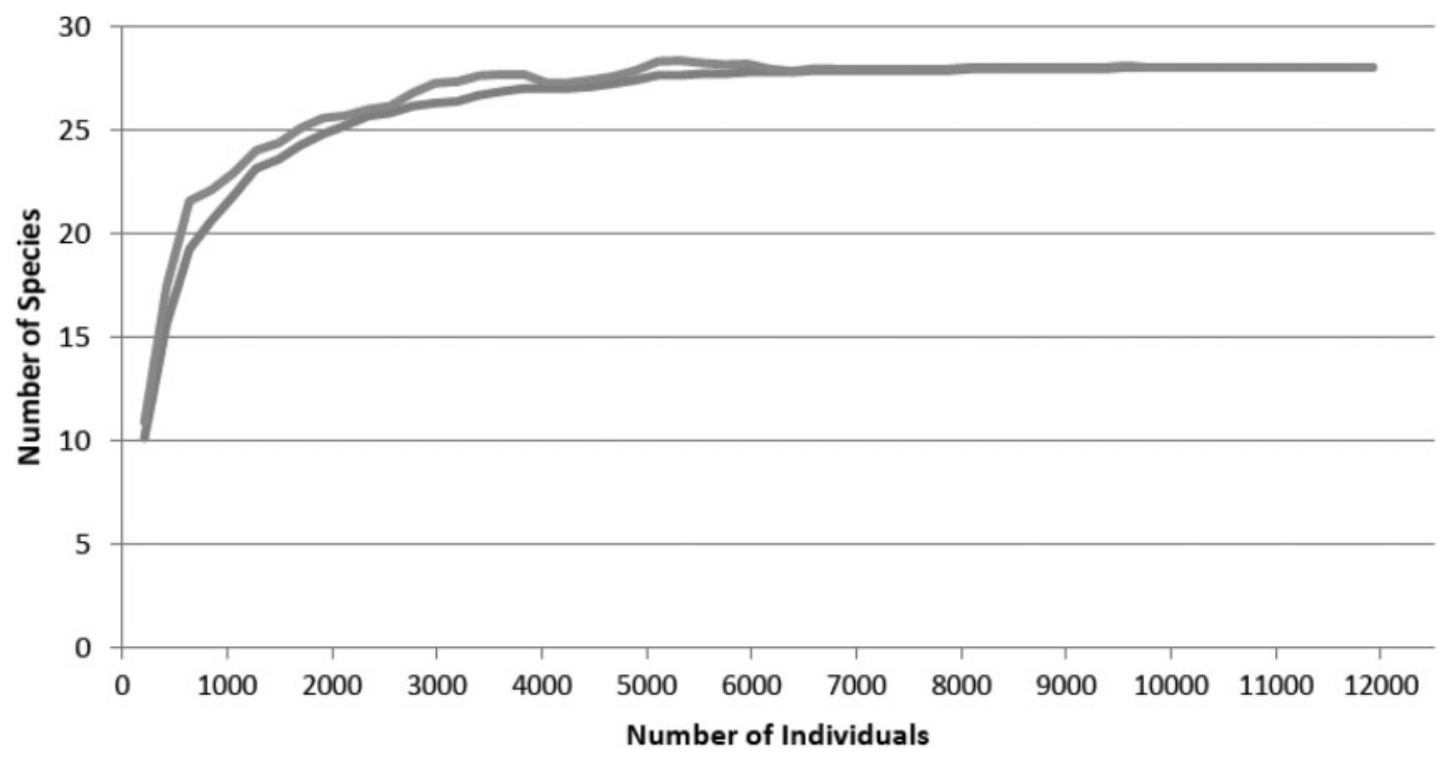

Species Accumulation Curve $\quad$ Chao 1 Mean

Fig. 5. Species accumulation curve and Chao 1 mean for Bombus in Montana. Figure was generated using EstimateS (Colwell 2013). Each county was considered a sample and samples were randomized 50 times to create the mean accumulation curve.

and B. ternarius, may suggest the presence of $B$. perplexus in the northeastern part of Montana.

\section{Sympatry of Eastern/Western Species Pairs}

In North America, there are several morphologically similar species thought to have ranges that are geographically distinct (i.e., one species is said to be "eastern", the other "western"; Colla et al. 2011, Koch et al. 2012, Williams et al. 2014). This geographic distinction is often used to aid in species diagnosis. The division between eastern and western North America is often split at the 100th meridian, but that separation is relatively arbitrary. Because Montana's eastern border is near the 100th meridian, eastern Montana is one area where eastern and western species ranges may overlap. This project has confirmed the sympatric occurrence of three of these species pairs: B. auricomus/B. nevadensis, Bombus huntii Greene/B. ternarius, and B. occidentalis/B. terricola.

\section{Bombus auricomus/Bombus nevadensis}

Throughout their taxonomic histories, B. nevadensis and B. auricomus have been considered either separate species or subspecies (Hurd 1979). Currently, they are considered separate species, with B. nevadensis occurring in western North America and B. auricomus in the East (Williams et al. 2014). Bombus nevadensis is considered common throughout its range (Koch et al. 2012) and is widespread in Montana (252 specimens in 41 counties; Fig. 4s). On the other hand, the presence of $B$. auricomus in Montana was uncertain prior to this study, though its occurrence here was predicted by Milliron (1971). Bombus auricomus is a common eastern species known to occur throughout eastern temperate forests west to the Great Plains (Williams et al. 2014). We documented five specimens of B. auricomus in four Montana counties reaching as far west as Pondera County (Fig. 4b). These records extend the known range of B. auricomus west to the foothills of the Rocky Mountains $\left(111.506^{\circ} \mathrm{W}\right)$, and suggest an extensive area of $B$. auricomus/B. nevadensis sympatry across the eastern two-thirds of Montana (compare Fig. $4 \mathrm{~b}$ and Fig. 4s).

\section{Bombus huntii/Bombus ternarius}

Bombus huntii and B. ternarius are morphologically similar, but they have been thought to be geographically distinct. Bombus huntii is said to replace $B$. ternarius in the interior western United States, while $B$. ternarius replaces $B$. buntii in the North (Williams et al. 2014). Across much of Montana, however, these two species occur sympatrically (compare Fig. $4 \mathrm{~m}$ and Fig. 4z). In Montana, B. huntii is one of the most common and widespread species. The earliest specimen was collected in 1883 , and it has been consistently collected since that time across the entire state (Fig. $4 \mathrm{~m}$ ). Conversely, only six specimens of B. ternarius were collected before 2008 and added to the database. However, since 2011, when the Montana Department of Agriculture began using bucket traps to monitor for invasive pests in eastern Montana, many more individuals of B. ternarius have been collected, and it has become one of the most commonly collected species in the northeastern portion of the state (Fig. $4 \mathrm{z}$ ).

\section{Bombus occidentalis/Bombus terricola}

The range of $B$. occidentalis is extensive across western North America (Williams et al. 2014), and this species was once one of the most common bees in the West. However, since the 1990s, some populations have experienced sharp declines (Cameron et al. 2011, Williams et al. 2014). Bombus terricola is an eastern and northern North American species (Williams et al. 2014), known to be in the Black Hills area of South Dakota (Koch et al. 2012) and predicted to be as far west as eastern Montana (Milliron 1971, Koch et al. 2012, Williams et al. 2014). It has been collected in Alberta east of Edmonton, and in northwestern Alberta near Valleyview and Grande Prairie (A. Sturm, personal communication). These two species are thought to be geographically distinct with $B$. occidentalis replacing $B$. terricola in the West. Literature records placed B. terricola in multiple locations across Montana (Frison 1923, Kral 1955, Williams et al. 2014). However, upon examination of many of the specimens associated with those records, nearly all of the B. terricola records from Montana are $B$. occidentalis according to current 
taxonomic understanding (Koch et al. 2012, Williams et al. 2014). We did collect nine specimens of $B$. terricola from far northeastern Montana (MTEC): one from 2011 and eight in 2015 (Fig. 4aa). There is one more verified B. terricola specimen determined by Franklin in 1922 (ANSP), but it lacks a date or specific locality. Bombus occidentalis has been collected in 41 Montana counties (Fig. 4t), but has not yet been collected in the southeastern-most region of Montana, where B. terricola is also likely to be found. However, we now have records of these two species being sympatric, at least in the two northeastern-most counties of Montana (compare Fig. 4t and Fig. 4a).

\section{Taxonomic Challenges}

When it comes to identifying bumble bees, a frequently documented challenge is the extraordinary intra- and interspecific variation in the color patterns of the hair-like setae (hereafter referred to as hairs) occurring among members of a species (Milliron 1971, Williams 1998, Owen et al. 2010). This difficulty is exacerbated by the tendency of multiple species to converge on similar color patterns when occupying similar geographic locations (Williams 1998). Recent DNA evidence confirms that species can be extremely difficult (or even impossible) to identify by morphological characters alone, as there appears to be phenotypic convergence of genetically distinct species (Williams 2007, Koch 2015). In Montana, especially western Montana with its elevational diversity, the variation in color patterns is accompanied by noticeable differences in hair length and texture (Milliron 1971, A.C.D., unpublished data), making identification even more challenging. For the species pairs described below, characters use to distinguish between similar species are for females only. Male determination requires examination of genitalia (see Williams et al. 2014 for more information on identification of males).

\section{Bombus auricomus/Bombus nevadensis}

As discussed above, B. auricomus and B. nevadensis are morphologically similar species that were thought to be geographically distinct. Both occur in Montana, and distinguishing between them using morphological characters is extremely difficult. The main morphological character used to tell these species apart is the presence or absence of a black interalar band. Bombus auricomus typically has a strong black interalar band, while B. nevadensis usually has yellow hairs predominating dorsally on the mesosoma with only a circle of black hairs medially. Another diagnostic character used is the size and spacing of punctations between the eyes and the ocelli (Williams et al. 2014), but the very subtle spacing differences make this character difficult. Some individuals are especially difficult to distinguish because the circular patch of black hairs on B. nevadensis is expanded into a nearly complete interalar band, more closely resembling B. auricomus, though this color variant is most common on the West Coast of the United States. For this study, we relied on a complete black interalar band as diagnostic for B. auricomus. Therefore, if the black hairs on the thorax extended to the wing bases, even if there were a few yellow hairs intermixed, we determined the specimen to be B. auricomus. If, however, most of the hairs touching the wing bases were yellow, we determined it to be B. nevadensis.

\section{Bombus huntii/Bombus ternarius}

As discussed above, B. huntii and B. ternarius are morphologically similar species previously thought to be geographically distinct. However, because they occur sympatrically across much of Montana, geographic location cannot be used to aid determinations.
Key morphological characters, however, can be used to tell these two species apart. Bombus ternarius has black hairs on the face with yellow hairs located centrally near the antennal bases, and the yellow hairs on the scutellum are divided by a line or triangle of black hairs. Often there are also yellow hairs on the front coxae. In $B$. huntii, the yellow hairs of the scutellum are not divided by black, the hairs on the face are predominantly yellow, and the hairs on the coxae are completely black.

\section{Bombus occidentalis/Bombus terricola}

As discussed above, B. terricola and B. occidentalis were thought to be geographically separated as eastern and western North American species, but both occur in Montana. For these two species, key morphological characters can be used for determination. Bombus terricola has metasomal T2 ( $\mathrm{T}=$ tergite) entirely yellow while $B$. occidentalis always has at least some black on $\mathrm{T} 2$.

\section{Bombus californicus/Bombus fervidus}

Bombus fervidus is a widespread species that has been collected transcontinentally in North America while B. californicus is a western species known from the Pacific Coast to the Rocky Mountains (Koch et al. 2012, Williams et al. 2014). Historically, there has been difficulty distinguishing between certain forms of B. californicus and B. fervidus (Stephen 1957), and the two have been considered synonymous by some (Milliron 1973a, Williams et al. 2014). However, where the two species are sympatric, $B$. fervidus occurs mostly in the prairies, whereas B. californicus occurs in forested foothills (Thorp et al. 1983). New molecular data provide further evidence that the two are distinct species, though they can be phenotypically convergent (Koch 2015). Based on this, we treat them as separate species in Montana. The two appear to be sympatric in the western counties, though our collection sites and observations support the ecological distinction. Bombus fervidus is widespread in the prairie-type habitats of eastern Montana and was collected all across the state to the western border. Bombus californicus was collected only in the mountainous regions of western Montana (compare Fig. 4f and Fig.4h).

Bombus californicus has several different color morphs, some more cryptic than others. Metasomal T4 is always yellow, as in B. fervidus, while T1-T3 are variable in color. Some forms have T1-T3 completely black while others have T1-T3 almost completely yellow with only small patches of black laterally on T2. Identification is complicated by a spectrum of intermediate color patterns between these two extremes (Williams et al. 2014, Koch 2015). Based on our observations, B. fervidus in Montana have only yellow hairs on T1-T4.

\section{Bombus centralis/Bombus flavifrons}

Certain individuals of $B$. centralis are very similar to $B$. flavifrons. Both species have a longer-than-wide malar space and a hair pattern of metasomal T1: yellow, T2: yellow, T3: orange, and T4: orange. The key morphological character that separates these two is the amount of black hair intermixed with yellow on the anterior scutum. However, this character is not often clear-cut. In fact, the blending of diagnostic characters occasionally makes separation impossible (Stephen 1957, A.C.D., unpublished data). Some individuals can easily be identified as one species or the other, but in many cases there appears to be more of a spectrum of B. centralis-B. flavifrons than two distinct species groups. In general, $B$. flavifrons is found in more forested, montane areas, while B. centralis is found more in the plains and valleys (Thorp et al. 1983; Fig. 4g and j; 
A.C.D., unpublished data). Because these habitats often overlap in Montana, the species also occur in both habitats.

We used the amount of black hairs on the anterior scutum and the general length of the body hairs as our main diagnostic characters. If only a few black hairs were intermixed on the anterior scutum and the body hairs were generally short and even, we identified the specimen as B. centralis. If more than just a few hairs were intermixed on the anterior scutum and the hairs were generally longer and more uneven, we identified the specimen as B. flavifrons. If an identification of $B$. centralis or $B$. flavifrons was not obvious, we defaulted to an identification of $B$. flavifrons, following the recommendation of James Strange at the BLCU in Logan, UT. A few especially difficult specimens were identified only as Bombus sp. with a note indicating the specimen was either B. flavifrons or B. centralis.

\section{Species Introduced to Montana}

Bombus impatiens is a common eastern North American species whose native range extends only as far west as Nebraska and Minnesota (Williams et al. 2014). It has been commercially reared for greenhouse pollination services and research since the 1980 s (Koppert Biological 2015). Concerns have been raised about the transport of this species to the western United States and the possible consequences for native bees if feral $B$. impatiens colonies become established outside of their native range (Xerces Society et al. 2013). Commercial hives contain queen excluders in order to prevent the escape of new queens and the establishment of feral colonies (Planet Natural 2016). Still, the use of these colonies is of some concern, with potential consequences including the development of feral colonies by escaped queens, pathogen spillover (McMahon et al. 2015), and competition with native pollinators (Potts et al. 2010, Morales et al. 2013, Graystock et al. 2016).

There was one record of this species in Montana from a 2005 study (Fultz 2005), but this record could not be validated because the specimen could not be located.

The database currently contains seven specimens of B. impatiens from Montana (Fig. 4n). One verified specimen of B. impatiens was collected in Ravalli County in June of 1980 from a locality on the western side of the continental divide, well beyond the known range of B. impatiens and before the widespread use of B. impatiens as a commercial pollinator (Snow Entomological Museum Collection, University of Kansas, SEMC). The other six specimens of B. impatiens are from a research project using commercially reared $B$. impatiens in a comparison between organic and conventional wheat fields in Chouteau County. These six records were added to the database as documentation in case feral colonies of this species are detected in that region in the future. At the end of the summer 2014 field season, individuals of $B$. huntii were found inside these commercial B. impatiens colonies (MTEC 019701, MTEC 019702), documenting that native and commercially reared bees are interacting in the wild, providing a potential pathway for pathogen and parasite transfer from imported colonies to native bees (Graystock et al. 2016).

\section{Species Possibly in Decline}

The purpose of our project was to provide baseline data and general distribution data for Bombus species occurring in Montana. We did not attempt to use these data to form conclusions about population trends or changes in historic ranges. Still, our results show that, of the 28 species collected, records for all but two experienced an increase of $\geq 49 \%$ since 2000 when sampling efforts in Montana substantially increased. The increase in records of $B$. occidentalis is just
$36 \%$ since 2000 , and only five individuals of B. suckleyi have been added to the database since 2000 (MTEC, BLCU, KMOC), representing only a $4 \%$ increase. These relatively low percentage increases are consistent with reported population declines for these species (Cameron et al. 2011; Hatfield et al. 2015a,b; Koch et al. 2015).

Changes in the prey composition of natural enemies over the past $50 \mathrm{yr}$ may also be reflective of population declines in $\mathrm{B}$. occidentalis. Armitage (1965) found B. occidentalis to be the most common prey (35\% of 203 Bombus spp.) of the wasp Philanthus bicinctus Mickel at a site on the southern edge of Yellowstone National Park $(50 \mathrm{~km}$ south of Montana). Forty years later, however, Dukas (2005) found that B. rufocinctus was the primary prey of the wasp at the same site, though he does not indicate whether $B$. occidentalis was among the remaining prey.

It has been hypothesized that the decline of B. suckleyi is associated with the observed decline of $B$. occidentalis, its primary host (Hatfield et al. 2015b). In Montana, which is at the center of the historic range of B. occidentalis (Cameron et al. 2011), there has not been a great deal of concern about populations declining. Because of this, the low number of B. suckleyi collected in the past $15 \mathrm{yr}$ initially seemed a bit surprising. No standardized population assessment has yet been conducted in Montana, so it is not appropriate at this time to form conclusions about the populations of any of Montana's species. However, it is clear that more work is needed to assess the true range, status, and habits of both B. suckleyi and its primary host, $B$. occidentalis, in Montana.

\section{Notes on Sampling Methods}

Many of the bumble bees collected in Montana over the past $130 \mathrm{yr}$ and examined for this project were captured using a net. However, other methods were also used to obtain specimens, including pan traps, pitfall traps, flight intercept traps, bucket traps, and Japanese beetle traps. In most cases, the bumble bees collected by these traps, excluding pan traps, would be considered "by-catch," because they are commonly used to sample non-Hymenopteran taxa. Typically, nontarget species collected in these traps are stored but not processed, or discarded. Even the small and biased samples of nontarget bee species collected by nontraditional trapping methods provide valuable insights when added to larger specimen and literature databases (Hung et al. 2015, Spears and Ramirez 2015). In our study, by-catch provided samples from a variety of localities throughout Montana that may not otherwise have been represented (e.g. Ivie et al. 1998, Winton 2010).

Because bucket and Japanese beetle traps are extremely effective at attracting bumble bees, their use is very enticing. We advise that anyone utilizing these traps in the future should exercise caution and deploy them at very low densities since the large number of bees captured could drastically reduce populations of nearby colonies. Due to limitations in time and travel, our 2015 traps were set up in May and left up throughout the summer. Consequently, all castes of bees were collected, including a large number of queens. We would caution against using these traps early in the spring or summer and late in the summer when queens are active, since the capture of queens compared to workers potentially has a much greater impact on colony establishment. In addition, because the yellow color and floral scents used as lures in Japanese beetle and bucket traps make them highly attractive to bees, we encourage the development of alternative trap colors and lures that effectively collect target species while avoiding the unnecessary capture of nontarget pollinators. 


\section{Key to Female Bumble Bees of Montana (Adapted From Koch et al. 2012 With Additional Notes From Williams et al. 2014)}

The following key is to female bumble bees only. To identify males, we recommend Bumble Bees of North America
(Williams et al. 2014). The key includes all 28 species recorded from Montana along with four species that might be found here. Morphological characters used in the key are shown in Figure 6. When color is used in the key, it refers to the color of the hair-like setae (referred to as "hairs") unless otherwise stated.
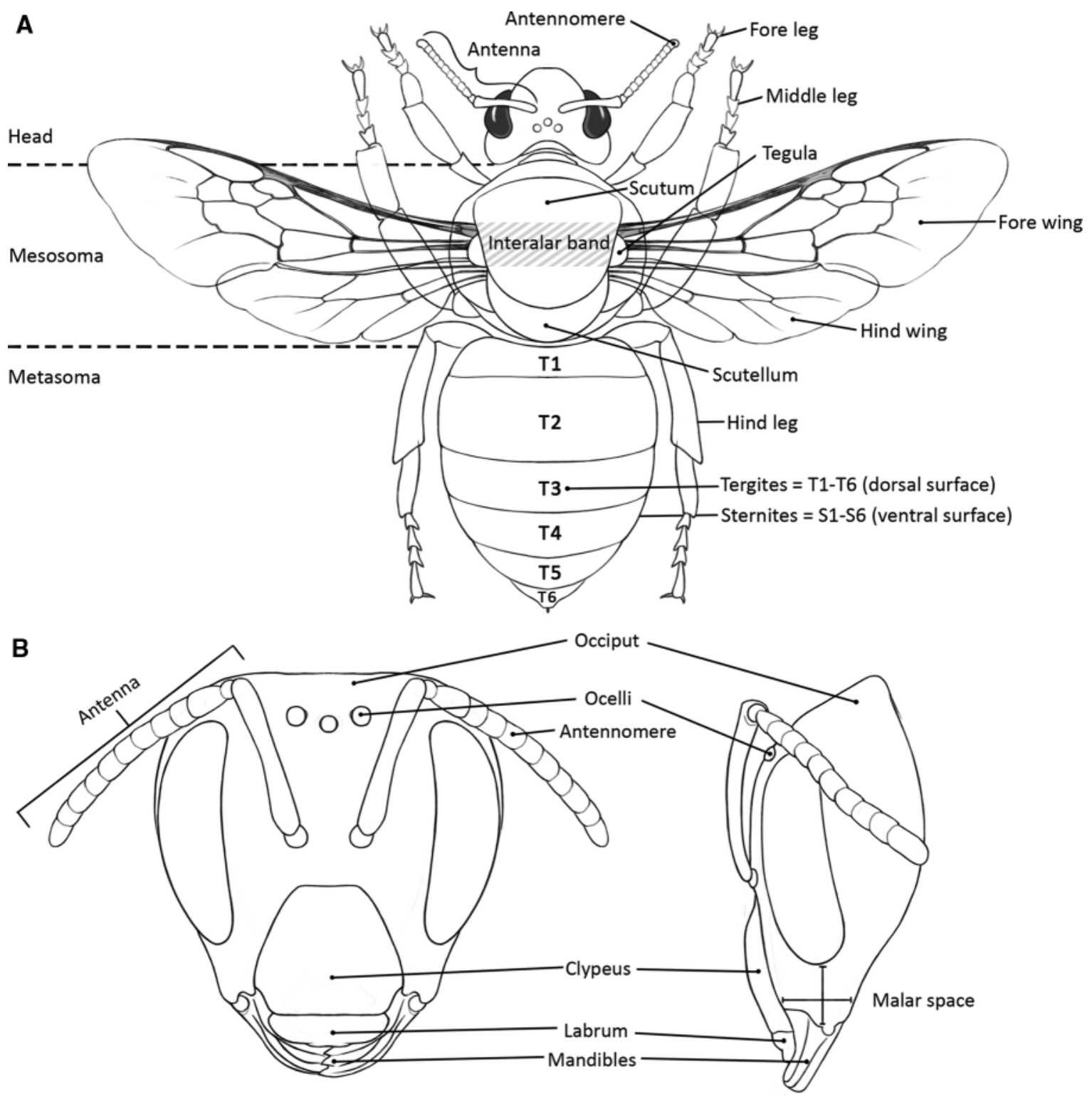

C

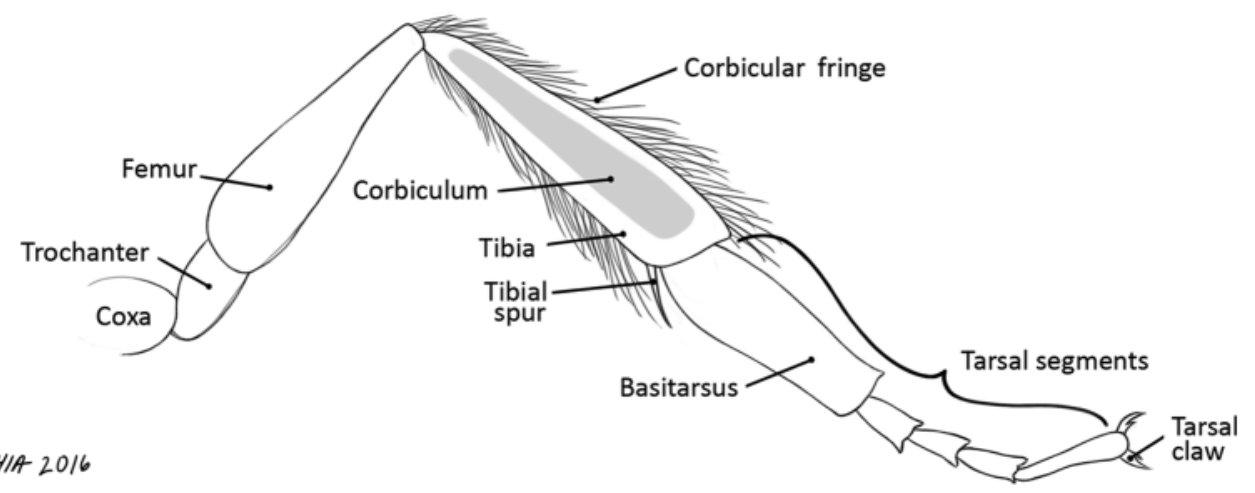

Fig. 6. (A-C). Morphological characters used to identify female Bombus to species. 
One of the most challenging characters used to identify bumble bees is the length of the malar space compared to its width. The length of the malar space is measured from the lower margin of the compound eye to the mandibular hinge. The width of the malar space is measured from the edge of the anterior mandibular hinge to the posterior hinge (Fig. 6b). This character is best viewed in profile. In general there are three malar-space lengths: 1) shorter than wide, 2) as long as wide, and 3) longer than wide. There is considerable variability within these categories, and it takes practice to learn to identify these with confidence.

Detailed species accounts, along with a summary of key diagnostic characters can be found on the Montana Entomology Collection website (Dolan et al. 2016) and in Dolan (2016).

1. Female: antenna with 12 antennomeres; metasoma with six visible tergites

1'. Male: antenna with 13 antennomeres; metasoma with seven visible tergites. No key provided. (To key males to species, use Williams et al. 2014.)

2(1). Outer surface of hind tibia concave and shiny; corbicula present; social species

2'. Outer surface of hind tibia convex and hairy; corbicula absent; social parasites. ...35

3(2). T2 and T3 with red or orange hairs, sometimes with yellow hairs intermixed at least medially.....

3'. T2 and/or T3 with yellow or black hairs

4(3). Scutum anterior to wing bases with yellow and black hairs intermixed, giving cloudy appearance.

4'. Scutum anterior to wing bases with predominantly yellow or pale yellow hairs.....

5(4). T2 with black hairs at least medially; integument of hind leg basitarsus brownish-orange and often lighter than the tibia; corbicular fringes orange or brown.

.Bombus bifarius Cresson

5. T2 orange; hind tibia and basitarsus concolorous; corbicular fringes black, sometime with orange tips............. ..........................Bombus melanopygus Nylander

6(4'). Malar space distinctly shorter than wide; face with predominantly black hairs

Bombus rufocinctus Cresson

6. Malar space as long as wide; face with yellow hairs, at least centrally .

$7\left(6^{\prime}\right)$. Scutellum with yellow hairs only ...... Bombus huntii Greene

7'. Scutellum with yellow or pale yellow hairs divided by a line or triangle of black hairs

$8\left(7^{\prime}\right)$. T2 color variable, but with black hairs at least medially; integument of hind leg basitarsus brownish-orange and often lighter than the tibia ........... Bombus bifarius Cresson

8'. T2 predominately orange, lacking black hairs medially; integument of hind leg basitarsus and tibia concolorous.....9

9(8'). T5 with yellow hairs on the lateral margins; hairs long and uneven; coxae with predominately black hairs..........................Bombus sylvicola Kirby

9'. T5 black; hairs short and even; coxae often with yellow hairs Bombus ternarius Say

10(3'). Malar space longer than wide (though sometimes only slightly longer than wide and appearing square)

...11

10'. Malar space as long as or shorter than wide.............25

11(10). Face with pale white or yellow hairs, sometimes with black hairs intermixed, giving cloudy appearance...................... 12

11'. Face with predominantly black hairs................................16 12(11). T3 and T4 black ....................... Bombus flavifrons Cresson
12'. T3 and T4 orange or yellow or brownish. ............. 13

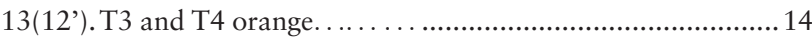

13'. T3 and T4 yellow or brownish. .................................... 15

14(13). Anterior scutum with black and yellow hairs intermixed, giving cloudy appearance ........Bombus flavifrons Cresson

14'. Anterior scutum with predominantly yellow hairs... ...............................mbus centralis Cresson

15(13'). T5 yellow or brownish.......... Bombus appositus Cresson 15'. T5 usually mostly black............. Bombus borealis Kirby

16(11'). T5 and T6 with orange or pale orange hairs.............. .......................... Bombus kirbiellus Curtis

16'. T5 and T6 with black hairs ........................................... 17

17(16'). T3 with mostly black hairs.............................................18

17'. T3 with yellow hairs at least medially .............................2 21

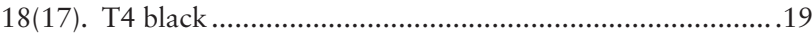

18'. T4 yellow ..................................Bombus californicus Smith

19(18). T2 with yellow hairs medially and black hairs laterally (yellow often in the shape of a "W") ......................... Bombus bimaculatus Cresson

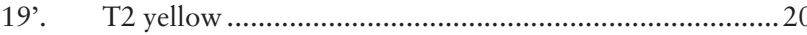

$20\left(19^{\prime}\right)$. Sides of the thorax with yellow hairs predominating.....

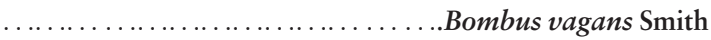

20'. Sides of the thorax usually with black hairs predominating .............Bombus perplexus Cresson (possibly in MT)

21(17'). Interalar band completely or predominantly black ..........22

21'. Interalar band predominantly yellow, if black hairs are present they form a small circle medially................ .......................... Bombus nevadensis Cresson 22(21). T4 black .23

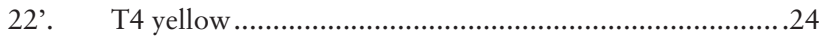

23(22). T1 usually with yellow hairs; surface of clypeus with many pits and punctures..........Bombus pensylvanicus (DeGeer)

23'. T1 with black hairs, at least medially, sometimes with yellow hairs intermixed; surface of clypeus smooth and shiny................... Bombus auricomus (Robertson)

24(22'). T2 yellow........................Bombus fervidus (F.)

24'. T2 with yellow hairs medially and black hairs laterally........................Bombus californicus Smith

25(10'). Malar space shorter than wide........................26

25'. Malar space as long as or slightly longer than wide... . . 31

26(25). Interalar band completely or predominantly black..............

26. Interalar band predominantly yellow; if black hairs are present they form a small circle medially .............................. 30

27(26). T1 yellow ............................... Bombus rufocinctus Cresson

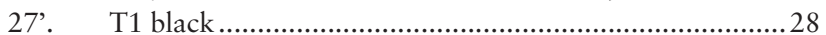

$28\left(27^{\prime}\right)$. T2 yellow ………….................................................... 29

28'. T2 with black hairs or, if some yellow, along posterior margin only Bombus occidentalis Greene

29(28). T3 black................Bombus cryptarum (F.) (possibly in MT) 29'. T3 yellow. Bombus terricola Kirby

30(26). T3 yellow, at least medially ..............Bombus morrisoni Cresson (possibly in MT) 30'. T3 black Bombus griseocollis (DeGeer)

$31\left(25^{\prime}\right)$. Scutellum with yellow or pale yellow hairs divided by a line or triangle of black hairs .............. Bombus bifarius Cresson

31'. Scutellum not as above (with yellow hairs only, or yellow and black hairs intermixed throughout)............................ 32

32(31'). T2-6 black. . . . . . . . . . . . . ................. . . . . . . impatiens Cresson (nonnative species introduced in MT)

32'. T2-6 with some yellow and/or orange .......................33 
33(32'). Anterior scutum with black and yellow hairs intermixed, giving cloudy appearance. . .34

33'. Anterior scutum with yellow hairs only............... ................................ Bombus frigidus Smith

34(33). Scutellum distinctly darker (with many black hairs intermixed with yellow) than anterior scutum..

Bombus sitkensis Nylander

34'. Scutellum and anterior scutum not as above (either with scutellum and anterior scutum similar in appearance, or with the scutellum appearing lighter than the anterior scutum) ...

Bombus mixtus Cresson

$35\left(2^{\prime}\right)$. Occiput with predominantly black hairs; hairs of face predominantly black around bases of antennae; S6 with strong lateral ridges ....37

35'. Occiput with predominantly yellow hairs; other characters variable.

. .36

$36\left(35^{\circ}\right)$. Hairs of face predominantly black around bases of antennae; lateral ridges not apparent on S6 (there may be small bumps); T6 often tightly curled under the abdomen... ............................Bombus flavidus Eversmann

36' Hairs of face predominantly yellow around bases of antennae; S6 with evenly rounded lateral ridges..... .............................. Bombus insularis (Smith)

$37(35)$. Hairs on the side of the thorax predominantly yellow; T4 yellow but with a triangle of black hair medially; S6 lateral ridges extending laterad beyond $\mathrm{T} 6$.

Bombus suckleyi Greene

37'. Hairs on the side of the thorax predominantly black; T4 yellowish-white to white, at least medially; S6 lateral ridges barely extending laterad beyond $\mathrm{T} 6 \ldots \ldots \ldots \ldots \ldots . . . . .$. ................Bombus bohemicus Seidl (possibly in MT)

\section{Acknowledgments}

This project would not have been possible without the help and support of a large number of people. Frank Etzler, Paloma Amaral, Charles Hart, Donna Ivie, Ian Foley, and Lauren Kerzicnik traveled many miles all over Montana during the summer of 2015 to help collect bumble bees and/or put up insect traps. Frank Etzler also hand-carried a bumble bee loan from Yale University to Montana. Paloma Amaral, Joe Wood, Dayane Andrade dos Reis, Alyssa Piccolomini, Lisa Seelye, Elizabeth Reese, Justin Runyon, Adrian Massey, Frank Etzler, Charles Hart, Donna Ivie, and Tyler Kelly helped process specimens. Lauren Kerzicnik forwarded a request for bumble bee collecting volunteers to the Extension Agents and Master Gardeners across the state, and served as the recipient of those specimens in the MSU Schutter Diagnostic Lab. Volunteers that sent in specimens included Patti Armbrister, Cynthia Mernin, Misty Miles, Sean Foley, Kevin Foley, Katie Foley, Kari Lewis, Janet Hamill, and Patti Fulton. Tabitha Graves and Joseph Giersch contributed specimens collected at their USGS project sites in Glacier National Park. James Beck created all maps in this work and designed and manages the MTEC website and the MTEC XBio:D database. Tyler Kelly, Elizabeth Reese, and Lisa Seelye tested the key and offered valuable feedback. Norman Johnson, Joe Cora, and Sara Hemley at The Ohio State University offered a great deal of assistance throughout the process of databasing all the records. James Strange, Jonathan Koch, and Robbin Thorp verified troublesome identifications and answered morphological or diagnostic questions. Robert K.D. Peterson, Christopher Brown, and Tyler Kelly contributed photographs to the website. Catherine L. Delphia created Figure 6. Many thanks to Paul Williams, Robbin Thorp, and two anonymous reviewers for offering valuable feedback on an earlier version of the manuscript.

We would like to thank the following individuals, collection managers, curators, and database managers for their contributions to the over 12,000 Bombus records from Montana. Brian Thompson, Hayes Goosey, and Ruth O'Neill contributed specimens from various 2015 research projects at MSU.
Ian Foley, from the Montana Department of Agriculture, contributed specimens collected in CAPS project traps. Bethanne Bruninga-Socolar, from Rutgers University, New Brunswick, NJ, contributed records from her Ph.D. project in Montana. Leif Richardson, Harold Ikerd, Lawrence Gall, and John Ascher contributed lists of Montana Bombus from their databases. Jessamyn Manson, Monica Kohler, and Ashton Sturm, University of Alberta, Edmonton, shared records and observations about bumble bees in Alberta. The following individuals and institutions loaned specimens or hosted a visit to examine specimens: Jason Weintraub, Greg Cowper, and Jon Gelhaus, Academy of Natural Sciences, Philadelphia, PA; Luciana Musetti, C. A. Triplehorn Insect Collection, The Ohio State University, Columbus, OH; Catherine E. Siebert, Bozeman, MT; Christopher Grinter, Illinois Natural History Survey, Champaign, IL; the Laura Burkle Lab (which includes E. Reese, M. Simanonok, L. Heil, and S. Adhikari) at MSU; Jen Marangelo, Missoula Butterfly House and Insectarium; John Swann, Museum of Zoology, University of Calgary, Alberta; Brian Harris, Sean Brady, and Floyd Shockley, National Museum of Natural History, Washington, D. C.; Leonard Munstermann and Lawrence Gall, Peabody Museum of Natural History, Yale University, New Haven, CT; Jennifer Thomas and Zachary Falin, Snow Entomological Museum, University of Kansas, Lawrence; Virginia Scott, University of Colorado Museum of Natural History, Boulder, CO.

The Montana Department of Agriculture's (MDA) Specialty Crop Block Grant Program provided support for the portion of this project involving pollinators of huckleberries via a grant to M.A.I. Survey work in eastern Montana during 2015 was supported by MDA and USDA-APHIS contracts to M.A.I. for invasive species detection. Bumble bee specimens collected as part of a Western Sustainable Agriculture Research and Education (WSARE) grant (SW13-043) were included in this work. This is a contribution of the Montana Agricultural Experiment Station.

\section{References Cited}

Armitage, K. B. 1965. Notes on the biology of Philanthus bicinctus (Hymenoptera: Sphecidae). J. Kans. Entomol. Soc. 38: 89-100.

Anonymous. 1920. Biological surveys of states by the United States Department of Agriculture during 1919. Science 21: 40.

Bauer, P. 1983. Bumblebee pollination relationships on the Beartooth Plateau tundra of southern Montana. Am. J. Bot. 70: 134-144.

Brambila, J., L. D. Jackson, R. L. Meagher, D. Restom Gaskill, and A. Derksen. 2014. Plastic bucket trap protocol. United States Department of Agriculture Cooperative Agricultural Pest Survey, Washington, DC.

Burlingame, M. G., and K. R. Toole. 1957. A history of Montana volume I. Lewis Historical Publishing Company, Inc., New York, NY.

Burkle, L. A., J. C. Marlin, and T. M. Knight. 2013. Plant-pollinator interactions over 120 years: Loss of species, co-occurrence, and function. Science 339: 1611-1615.

Cameron, S. A., J. D. Lozier, J. P. Strange, J. B. Koch, N. Cordes, L. F. Solter, and T. L. Griswold. 2011. Patterns of widespread decline in North American bumble bees. Proc. Natl. Acad. Sci. USA 108: 662-667.

Chao, A. 1984. Nonparametric estimation of the number of classes in a population. Scand. J. Statist. 11: 265-270.

Chaplin-Kramer, R., E. Dombeck, J. Gerber, K. A. Knuth, N. D. Mueller, M. Mueller, G. Ziv, and A. Klein. 2014. Global malnutrition overlaps with pollinator-dependent micronutrient production. Proc. R. Soc. B. 281: 20141799.

Colla, S., L. Richardson, and P. Williams. 2011. Bumble bees of the eastern United States: A product of the USDA Forest Service, Washington, DC. and the Pollinator Partnership, San Francisco, CA.

Colla, S. R., F. Gadallah, L. Richardson, D. Wagner, and L. Gall. 2012 Assessing declines of North American bumble bees (Bombus spp.) using museum specimens. Biodivers. Conserv. 21: 3585-3595.

Colwell, R. K. 2013. EstimateS: Statistical estimation of species richness and shared species from samples. http://viceroy.eeb.uconn.edu/estimates.

De LucaP. A., and M. Vallejo-Marin. 2013. What's the 'buzz' about? The ecology and significance of buzz pollination.Curr. Opin. Plant Biol. 16: 429-35.

Discover Life 2016. Bombus morrisoni. http://www.discoverlife.org/20/q? search $=$ Bombus + morrisoni. 
Dolan, A. C. 2016. Insects associated with Montana's huckleberry (Ericaceae: Vaccinium globulare) plants and the bumble bees (Hymenoptera: Apidae) of Montana. M.S. thesis, Montana State University, Bozeman.

Dolan, A. C., J. Beck, C. Delphia, and M. A. Ivie. 2016. Bumble Bees of Montana. http://mtent.org/Projects/Bees\%20of\%20Montana/bumble_bees/ bumble_bees_home.html.

Droege, S., et al. 2012. The very handy manual: how to collect and identify bees and manage a collection. http://www.pwrc.usgs.gov/nativebees/ Handy\%20Bee\%20Manual/Handy\%20Bee\%20Manual.pdf.

Dukas, R. 2005. Bumble bee predators reduce pollinator density and plant fitness. Ecology. 86: 1401-6.

Figueroa, L. L., and E. A. Bergey. 2015. Bumble bees (Hymenoptera: Apidae) of Oklahoma: past and present biodiversity. J. Kans. Entomol. Soc. 88: 418-29.

Foley, I., C. Lay, and B. Eiring. 2011. Cooperative Agricultural Pest Survey Report. Montana Department of Agriculture. http://agr.mt.gov/agr/ Programs/PestMgt/CAPS/2011_CAPS_report_12_29.pdf.

Franklin, H. J. 1912. The Bombidae of the New World. Trans. Am. Entomol. Soc. 38: 177-486.

Franklin, H. J. 1915. Notes on Bombidae, with descriptions of new forms (Hym.). Entomol. News Philadelphia. 26: 409-17.

Frison, T. H. 1923. Systematic and biological notes on bumblebees (Bremidae: Hym). Trans. Amer. Ent Soc. 48: 307-26. (December 1922).

Fultz, J. E. 2005. Effects of shelterwood management on flower-visiting insects and their floral resources. M.S. thesis, Montana State University, Bozeman.

Goulson, D., E. Nicholls, C. Botias, and E. L. Rotheray. 2015. Bee declines driven by combined stress from parasites, pesticides, and lack of flowers. Science 347: 1435-1444.

Gotelli, N. J., and R. K. Colwell. 2011. Estimating species richness. Frontiers in measuring biodiversity. Oxford University Press, New York, NY.

Graystock, P., E. J. Blane, Q. S. McFrederick, D. Goulson, and W.O.H. Hughes. 2016. Do managed bees drive parasite spread and emergence in wild bees? International Journal for Parasitology: Parasites and Wildlife. (http://www.sciencedirect.com/science/article/pii/S2213224415300158).

Harder, L. D., and R.M.R. Barclay. 1994. The functional significance of poricidal anthers and buzz pollination: Controlled pollen removal from Dodecatheon. Funct. Ecol. 8: 509-517.

Hatfield, R., S. Jepsen, R. Thorp, L. Richardson, S. Colla, and S. Foltz Jordan. 2015a. Bombus occidentalis. The IUCN Red List of Threatened Species 2015. (http://www.iucnredlist.org/details/44937492/0).

Hatfield, R., S. Jepsen, R. Thorp, L. Richardson, S. Colla, and S. Foltz Jordan. 2015b. Bombus suckleyi. The IUCN Red List of Threatened Species 2015 (http://www.iucnredlist.org/details/44937699/0).

Holden, C. 2006. Report warns of looming pollination crisis in North America. Science 314: 397.

Hung, K. J., J. S. Ascher, J. Gibbs, R. E. Irwin, and D. T. Bolger. 2015. Effects of fragmentation on a distinctive coastal sage scrub bee fauna revealed through incidental captures by pitfall traps. J. Insect Conserv. 19: 175-179.

Hurd, P. D. 1979. Superfamily Apoidea, pp. 1741-2209. In K. V. Krombein, P. D. Hurd, D. R. Smith and B. D. Burks (eds.), Catalog of Hymenoptera in American north of Mexico. Smithsonian Institution Press, Washington, DC.

Ivie, M. A., L. L. Ivie, and D. L. Gustafson. 1998. The effects of the Red Bench fire of 1988 on beetle communities in Glacier National Park, Montana, USA, 1989-1993. Final Report of NPS-funded contract to Montana State University, NPS Cooperative Agreement CA 1268-1-9017. Bozeman, MT.

Kerr, J. T., A. Pindar, P. Galpern, L. Packer, S. G. Potts, S. M. Roberts, P. Rasmont, O. Schweiger, S. R. Colla, L. L. Richardson, et al. 2015. Climate change impacts on bumblebees converge across continents. Science 349: 177-180.

Koch, J. B. 2015. Biogeography, population genetics, and community structure of North American bumble bees. Ph.D. Dissertation. Utah State University, Logan.

Koch, J., J. Strange, and P. Williams. 2012. Bumble bees of the western United States. A product of the USDA Forest Service, Washington, D.C. and the Pollinator Partnership, San Francisco, CA.

Koch, J., J. Lozier, J. Strange, H. Ikerd, T. Griswold, N. Cordes, L. Solter, I. Stewart, and S. Cameron. 2015. U.S. Bombus, a database of contemporary survey data for North American Bumble Bees (Hymenoptera, Apidae, Bombus). U.S. Biodivers. Data J. 3: e6833.

Koppert Biological Systems 2015. Pollination. (http://www.koppert.com/polli nation/).

Kral, R. 1955. Bee visitors of Penstemon ellipticus (Scrophulariaceae) on Eddy Peak, Sanders County, Mont., in summer of 1954. Field Lab. 23: 31-34.

Lesica, P. 2012. Manual of Montana vascular plants. BRIT Press, Fort Worth, TX.

McMahon, D. P., M. A. Furst, J. Caspar, P. Theodorou, M.J.F. Brown, and R. J. Paxton. 2015. A sting in the spit: Widespread cross-infection of multiple RNA viruses across wild and managed bees. J. Anim. Ecol. 84: 615-624.

Michener, C. M. 2007. Bees of the world, 2nd edn. The Johns Hopkins University Press, Baltimore, MD and London, United Kingdom.

Milliron, H. E. 1971. A monograph of the western hemisphere bumblebees (Hymenoptera: Apidae; Bombinae) I. The genera Bombus and Megabombus subgenus Bombias. Mem. Entomol. Soc. Can. 82.

Milliron, H. E. 1973a. A monograph of the western hemisphere bumblebees (Hymenoptera: Apidae; Bombinae) II. The genus Megabombus subgenus Megabombus. Mem. Entomol. Soc. Can. 89.

Milliron, H. E. 1973b. A monograph of the western hemisphere bumblebees (Hymenoptera: Apidae; Bombinae) III. The genus Pyrobombus subgenus Cullumanobombus. Mem. Entomol. Soc. Can. 91.

Montana Wilderness Association 2015. Wilderness areas. (http://wildmon tana.org/discover-the-wild/montanas-public-lands/wilderness-areas/).

Morales, C. L., M. P. Arbetman, S. A. Cameron, and M. A. Aizen. 2013. Rapid ecological replacement of a native bumble bee by invasive species. Front. Ecol. Environ. 11: 529-534.

Morrill, A. W. 1903. New Apoidea from Montana. Can. Entomol. 35: 222-226.

O’Neill, K. M., H. E. Evans, and L. B. Bjostad. 1991. Territorial behaviour in males of three North American species of bumblebees (Hymenoptera: Apidae, Bombus). Can. J. Zool. 69: 604-613.

Owen, R. E., T. L. Whidden, and R. C. Plowright. 2010. Genetic and morphometric evidence for the conspecific status of the bumble bees, Bombus melanopygus and Bombus edwardsii. J. Insect Sci. 10: 1-18.

Pearce, A., K. M. O’Neill, R. S. Miller, and S. Blodgett. 2012. Diversity of flower-visiting bees and their pollen loads on a wildflower seed farm in Montana. J. Kans. Entomol. Soc. 85: 97-108.

Planet Natural 2016. Bumble Bees (Natupol®). (http://www.planetnatural. com/product/bumble-bees-natupol).

Potts, S. G., J. C. Diesmeijer, C. Kremen, P. Neumann, O. Schweiger, and W. E. Kunin. 2010. Global pollinator declines: Trends, impacts and drivers. Trends Ecol. Evolut. 25: 345-353.

Scott, V. L., J. S. Ascher, T. Griswold, and C. R. Nufio. 2011. The bees of Colorado (Hymenoptera: Apoidea: Anthophila). University of Colorado Museum of Natural History, Boulder.

Severin, H. C. 1926. The bumble bees of South Dakota. 16th Annual Report of the State Entomologist, Brookings, SD.

Simanonok, M. P., and L. A. Burkle. 2014. Partitioning interaction turnover among alpine pollination networks: Spatial, temporal, and environmental patterns. Ecosphere 5: 1-17.

Spears, L. R., and R. A. Ramirez. 2015. Learning to love leftovers. Am. Entomol. 61: 168-173.

Stephen, W. P. 1957. Bumble bees of western America (Hymenoptera: Apoidea). Tech. Bull. Oregon State College, Agric. Exp. Stn. 40: 1-163.

Thorp, R. W., D. S. Horning Jr., and L. L. Dunning. 1983. Bumble bees and cuckoo bees of California. Bull. Calif. Ins. Surv. 23: 1-79.

Tripodi, A. D., and A. L. Szalanski. 2015. The bumble bees (Hymenoptera: Apidae: Bombus) of Arkansas, fifty years later. J. Melitt. 50: 1-17.

Warriner, M. D. 2012. Bumble bees (Hymenoptera: Apidae) of Texas: Historical distributions. Southwest Nat. 57: 442-445.

Williams, P. H. 1998. An annotated checklist of bumble bees with an analysis of patterns of description (Hymenoptera: Apidae, Bombini). Bull. Nat. Hist. Mus. Entomol. 67: 79-152.

Williams, P. H. 2007. The distribution of bumblebee colour patterns worldwide: Possible significance for thermoregulation, crypsis, and warning mimicry. Biol. J. Linnean Soc. 92: 97-118. 
Williams, P. H., and J. L. Osborne. 2009. Bumble bee vulnerability and conservation worldwide. Apidologie 40: 367-387.

Williams, P., and S. Jepson. 2014. IUCN Bumble Bee Specialist Group Report 2014. (http://www.xerces.org/wp-content/uploads/2015/03/2014-bbsg-annual-report.pdf)

Williams, P. H., R. W. Thorp, L. L. Richardson, and S. R. Colla. 2014. An identification guide to the bumble bees of North America. Princeton University Press, Princeton, NJ and Oxford, United Kingdom.

Williams, P. H., A. M. Byvaltsev, B. Cederberg, M. V. Berezin, F. Odegaard, C. Rasmussen, L. L. Richardson, J. Huang, C. S. Sheffield, and S. T. Williams. 2015. Genes suggest ancestral colour polymorphisms are shared across morphologically cryptic species in arctic bumblebees. PLoS ONE 10: e0144544
Winfree, R., R. Aguilar, D. P. Vazquez, G. LeBuhn, and M. A. Aizen. 2009. A meta-analysis of bees' responses to anthropogenic disturbance. Ecology 90: 2068-2076.

Winton, R. C. 2010. The effects of succession and disturbance on Coleopteran abundance and diversity in the Centennial Sandhills. M.S. thesis, Montana State University, Bozeman.

Wyckoff, W. 2006. On the road again, Montana's changing landscape. University of Washington Press, Seattle, WA and Washington, DC.

Xerces Society for Invertebrate Conservation, National Resources Defense Council, and Defenders of Wildlife. 2013. Petition to regulate the movement of commercial bumble bees. (http://docs.nrdc.org/wildlife/files/wil_ 13102901a.pdf). 